\title{
Working
}

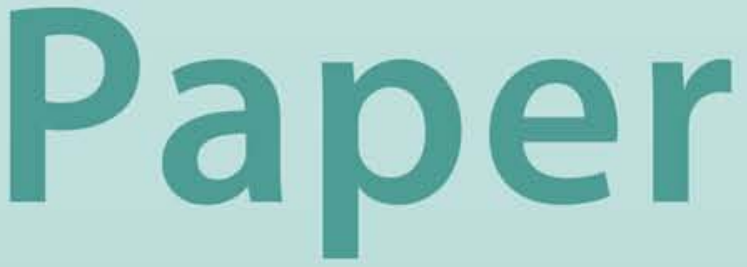


Financial Reforms, Financial Openness, and Corporate Borrowing: International Evidence

Şenay A ğca, Gianni De Nicolò, and Enrica Detragiache 


\title{
IMF Working Paper \\ IMF Institute
}

\section{Financial Reforms, Financial Openness, and Corporate Borrowing: International Evidence}

\section{Prepared by Şenay Ağca, Gianni De Nicolò, and Enrica Detragiache ${ }^{1}$}

July 2007

\begin{abstract}
This Working Paper should not be reported as representing the views of the IMF. The views expressed in this Working Paper are those of the author(s) and do not necessarily represent those of the IMF or IMF policy. Working Papers describe research in progress by the author(s) and are published to elicit comments and to further debate.

We study how credit market deregulation and increased international financial openness have changed corporate borrowing. The evidence comes from a large panel of publicly traded firms in 38 countries over the period 1994-2002. Reforms are measured with a comprehensive new index that tracks six separate dimensions. We find that these transformations have increased leverage and lengthened debt maturity in advanced economies, as expected, suggesting that in these countries corporate credit markets have become deeper. In emerging economies, the picture is more mixed: more international openness has led to more leverage but shorter debt maturity. Financial sector reforms have reduced leverage, while their effects on debt maturity have differed depending on the type of reform. Importantly, the differential impact of openness and reforms on the leverage and debt maturity of firms in advanced and emerging market countries also emerges when we distinguish between firms that are potentially financially constrained and firms that are not. These findings suggest that in emerging economies fundamental institutional weaknesses make it difficult to secure the benefits of international financial openness and domestic financial reforms.
\end{abstract}

JEL Classification Numbers: G15, G20, G32

Keywords: Corporate leverage, debt maturity, financial reforms, financial openness, international financial markets

Author’s E-Mail Address:sagca@gwu.edu, gdenicolo@imf.org, edetragiache@imf.org

\footnotetext{
${ }^{1}$ Şenay Ağca, School of Business, George Washington University; Gianni De Nicolò, Research Department, IMF; Enrica Detragiache, IMF Institute. We would like to thank Tsung-Ta Chiang, Radu A. Paun and Mark Parrett for research assistance.
} 


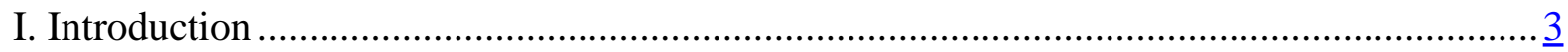

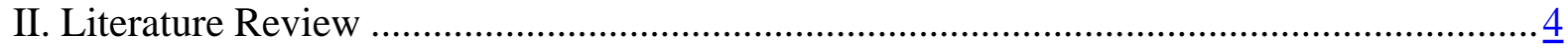

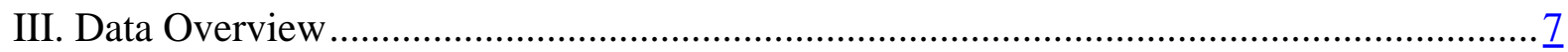

A. Leverage and debt maturity across countries and time................................... $\frac{7}{8}$

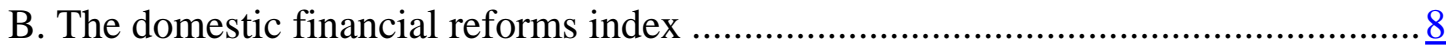

C. Financial Openness …................................................................................

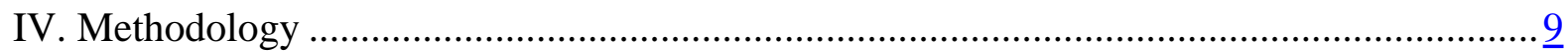

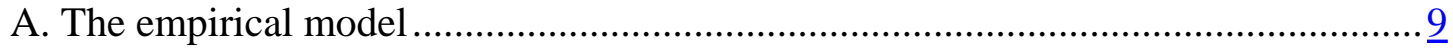

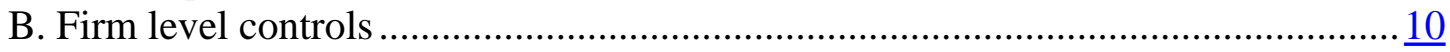

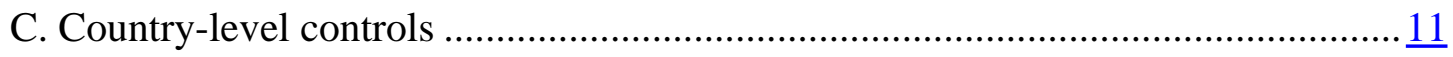

V. The Results .............................................................................................. 12

A. Leverage, debt maturity and firm characteristics ........................................... 12

B. The impact of some country specific characteristics .....................................13

C. The impact of domestic financial reforms and international financial openness ... $\underline{14}$

D. Disentangling the effects of financial reforms .......................................... $\frac{15}{16}$

E. Financial Constraints.......................................................................... $\frac{16}{18}$

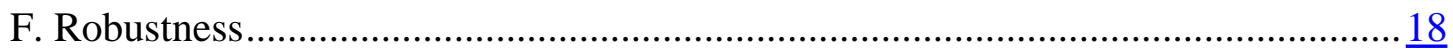

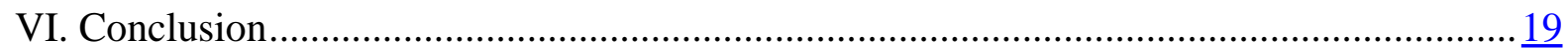

\section{Tables}

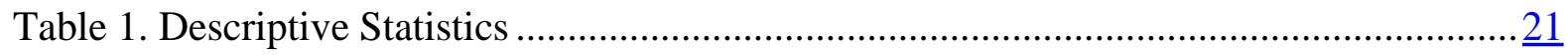

Table 2. Leverage, Financial Openness and Financial Liberalization.................................. $\underline{23}$

Table 3. Debt Maturity, Financial Openness and Financial Liberalization...........................25

Table 4. The Impact of Financial Openness and Financial Liberalization on

Leverage and Debt............................................................................................. 27

Table 5. Alternative Specifications with Financial Liberalization Index ............................. $\frac{31}{35}$

Table 6. Alternative Specifications with the Components of Financial Liberalization Index $\underline{35}$

Figures

Figure 1: Evolution of Leverage, Debt Maturity, DFL index and financial openness ............ $\underline{39}$

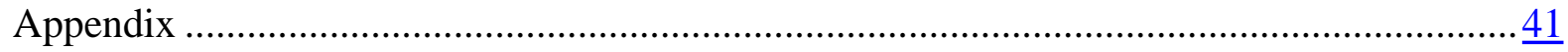

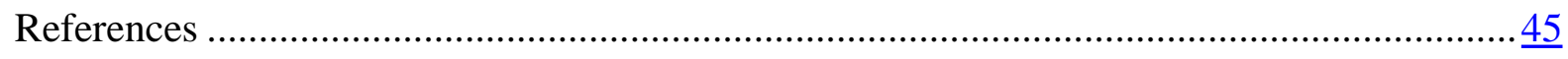




\section{INTRODUCTION}

In the past decade, the financial sector has undergone large transformations in most countries around the world. First, deregulation has increased the scope for financial markets in general and credit markets in particular to operate within each country. Second, increased international financial openness - in part the result of the dismantling of capital controls and in part the effect of technological innovations — has expanded firm financing options and increased competition among intermediaries. Have these transformation changed corporate borrowing? In this paper, we address this question using evidence from a large panel of nonfinancial firms in 38 countries during the period 1994-2002. More specifically, we study how corporate leverage and debt maturity change as domestic credit markets are reformed and access to international markets improves.

To measure domestic financial reforms aimed at improving the functioning of domestic credit markets we use a new index constructed by Abiad, Detragiache and Tressel (2007), which tracks policy changes in several areas. This index permits us to disentangle the effects of specific reforms, such as those aimed at liberalizing interest rates, eliminating credit controls, improving bank competition, and others. To gauge progress in international financial openness we adopt a measure of de facto reliance on international credit markets, the stock of private sector debt liabilities to foreign residents (scaled by GDP). Kose, and others (2006) argues that de facto measures better capture financial openness than de jure measure of capital account liberalization.

In our empirical tests, leverage and debt maturity are regressed on reform indicators, financial openness, a set of firm-level characteristics suggested by corporate finance theory, macroeconomic control variables, and industry and time fixed effects. ${ }^{2}$ Thus, we identify the effects of interest only based on within country, time-series variation, while cross-country differences in unobservable, time-invariant country characteristics do not bias the coefficients of our reform variables. Although our focus is on financial reforms and financial openness, a by-product of our analysis is detailed international evidence on the overall determinants of firms’ leverage and debt maturity which, as stressed by Myers (2004), may be useful in further refining theories of leverage and debt maturity choices.

With regard to international financial openness, we obtain two main results. First, more openness is associated with increased leverage. This indicates that the increase in competition among fund providers fostered by openness results in an increased availability of credit at a lower cost, as expected. Second, the impact of financial openness on debt maturity is different for firms in advanced and emerging countries: more openness is associated with a lengthening of debt maturity in advanced countries, but with a shortening of debt maturity in emerging economies. This result suggests that firms operating in countries where the financial

\footnotetext{
${ }^{2}$ See Korajczyk and Levy (2003) and Hackbarth, Miao and Morrellec (2006).
} 
infrastructure is less developed, and where short-term debt may be used more intensively as a disciplining device in the sense of Diamond (2004), may be able to access international credit markets primarily at short maturities. It is also possible that increased competition from foreign financial intermediaries and markets may lead domestic lenders to shorten debt maturity as existing relationship lending may be broken as arms-length finance becomes more prominent.

Turning to domestic financial sector reforms, we find that these reforms resulted in higher leverage and longer debt maturity in advanced countries, but in lower leverage in emerging economies. In addition, in emerging economies different types of domestic reforms affect debt maturity differently: bank privatization is associated with a decline in corporate debt maturity, policies to develop securities markets (including government bond markets) increase debt maturity, while other reforms have no significant effect.

The differential impact of openness and liberalization on the leverage and debt maturity of firms in advanced and emerging market countries also emerges when we distinguish between firms that are potentially financially constrained and firms that are not. The positive effect of openness and reforms on leverage is stronger for constrained firms in advanced countries, consistent with the hypothesis that reforms lead to financial deepening. In emerging economies, on the other hand, it is the unconstrained firms that seem to be the main beneficiaries of openness. The impact of financial reforms on debt maturity is not different for constrained and unconstrained firms in advanced economies. In emerging economies, on the other hand, bank entry and liberalization of interest rates reduce debt maturity only for constrained firms.

Overall, this evidence indicates that the reduction in funding costs and the increase in the availability of credit fostered by financial openness and liberalization may not be necessarily achieved at their full potential in emerging economies, likely because in these markets weaknesses in financial and institutional infrastructure, such as poor governance, accounting opacity and weak creditors' rights, persist.

The remainder of the paper is composed of five sections. Section II briefly reviews the literature. Section III describes the data, and the construction of our measures of domestic financial reforms and financial openness. Section IV details the specification of the statistical model of leverage and debt maturity. Section V contains the results, and Section VI concludes.

\section{LITERATURE REVIEW}

Most empirical research on corporate borrowing decisions uses U.S. data. Rajan and Zingales (1995) investigate corporate capital structures in a cross-country framework and find that most firm-specific variables that explain leverage in U.S. firms have a similar 
explanatory power for firms in other advanced countries. Booth, and others (2001) examine both leverage and debt maturity in ten developing countries and find that, while the set of explanatory variables used for firms in advanced economies works well also for firms in developing countries, the size of the relevant coefficients is quite different. In addition, they show that country characteristics (captured by country fixed effects) are as important as firm characteristics in explaining the sample variation in firm financing patterns, indicating the need to understand country-level determinants of these patterns.

A set of related studies has focused on debt maturity and its relationship with country characteristics. The results of these studies differ for different samples and time periods. Using data from the 1980s for a sample of 30 developed and developing countries, DemirgüçKunt and Maksimovic (2001) find that a more efficient legal system and a more liquid stock market are associated with longer debt maturity for large firms. For small firms, a deeper banking sector is associated with longer maturity, while the effects of stock market liquidity and legal efficiency are negligible. Furthermore, they find that indexes measuring the degree of minority shareholder protection and creditor protection in bankruptcy are not systematically related to debt maturity. When they examine the components of the creditor rights index, however, they find that the right of secured creditors to be paid first in bankruptcy shortens debt maturity for large firms, and automatic stay on assets increases debt maturity for small firms. Giannetti (2003), on the other hand, finds that stronger creditor protection in bankruptcy significantly increases debt maturity in a sample of European nonlisted companies. This result is also mirrored in Qian and Strahan (2007), in a cross-country sample of loan contracts including large, mostly global, loan issues. Qian and Strahan also find that countries with stronger creditor rights have longer debt maturities.

Fan, Titman, and Twite (2006) also examine the firm-level and country-specific determinants of both leverage and debt maturity in a broad sample of firms from 39 countries during the 1990s. They confirm the prior findings of Rajan and Zingales (1995) and Booth, and others (2001) regarding the impact of many firm-level determinants of leverage and debt maturity across countries. In addition, they find that leverage is higher in countries with more corruption and maturity is shorter in countries with more corruption and a deeper banking system. They also find that leverage is lower and debt maturity is longer in countries with a legal system based on common law.

Our analysis is linked with two other recent strands of the literature. The first strand examines the impact of bank deregulation on economic growth, credit availability, and credit quality. In the U.S., the relaxation of interstate banking and branching restrictions in the 1980s led to an acceleration of growth (Jayaratne and Strahan, 1996), to increased sensitivity of bank lending decisions to firm performance (Stiroh and Strahan, 2003), and to reduced entry barriers and improved access to finance for small-sized firms (Cetorelli and Strahan, 2006). The U.S. evidence on the benefits of bank deregulation is supported by studies of France and Italy. Bertrand, Schoar, and Thesmar (2004) find that, after the French banking 
industry was deregulated in 1985, bank lending decisions were more strongly influenced by firm performance; particularly, poorly performing firms were no longer bailed out by banks, resulting in more rapid industrial restructuring. In Italy, Guiso, Sapienza, and Zingales (2006) find that banking deregulation has led to improved access to credit and lower interest rate spreads, but also more nonperforming loans. ${ }^{3}$

The second strand of the literature has focused on the effects of international financial integration on economic growth. Recently, this literature has been comprehensively surveyed by Kose, and others (2006) and Henry (2006). Findings are generally mixed. When a large sample of countries is considered, countries that liberalize international capital flows faster or that become more financially integrated do not appear to exhibit faster growth. ${ }^{4}$ On the other hand, studies on the effects of opening up the stock market to foreign investors indicate substantial gains, both in terms of overall growth and growth opportunities (Bekaert, Harvey, Lundblad, 2005 and 2007), equity prices (Henry, 2000a), and investment (Henry, 2000b, Alfaro and Hammel, 2007).

Schmukler and Vesperoni (2006) (SV henceforth) study the impact of financial reforms on leverage and debt maturity, as we do. SV consider a sample of firms from seven emerging economies during the 1980-1998, and consider three reforms, each measured through a zero-one dummy variables: one for whether foreigners are allowed to invest in the local stock market (Bekaert and Harvey, 2000); one for the liberalization of the domestic financial sector, and one for the liberalization of controls on foreign capital flows (Kaminsky and Schmukler, 2003). Their main findings are that (i) liberalization does not have a significant impact on the leverage and debt maturity of firms that actively access global markets; (ii) liberalization leads to lower leverage and shorter debt maturity in firms that do not access global markets (although the effect of foreign capital flows liberalization is not significant). The authors conclude that the effects of financial liberalization are asymmetric in emerging economies, since firms that are not able to integrate in world capital markets appear unable to obtain long-maturity debt. We should note two limitations of SV's study. First, the sample consists of only seven emerging economies. Second, country-specific macroeconomic developments and global trends are not controlled for, so the liberalization dummies may act as proxies for these omitted variables.

\footnotetext{
${ }^{3}$ The benefits of financial liberalization seem to be less clear-cut as well. Financial liberalization has been associated to a higher incidence of banking crises (Demirgüç-Kunt and Detragiache, 1999) and more output volatility (Kaminsky and Schmukler, 2003). Townsend and Ueda (2006) find strong beneficial effects on welfare in Thailand, even though the growth effects are small.

${ }^{4}$ When a sub-sample of European countries is considered, the evidence appears consistent with positive growth effects of financial openness (Abiad, Leigh and Mody, 2007).
} 
In our analysis, we considerably extend the set of countries including advanced as well as emerging economies; we carefully control for global trends and for changes in the macroeconomic environment, and utilize comprehensive measures of financial reforms and financial openness. In addition, we gauge the consistency of our findings by examining the impact of financial reforms and financial openness for financially constrained and unconstrained firms separately.

\section{Data OVERVIEW}

Our dataset is composed of accounting and market data for a large sample of publicly traded firms (excluding financial firms and utilities) in 22 advanced and 16 emerging market countries over the period 1994-2002. ${ }^{5}$ Overall, the sample includes 76,147 firm-year observations, of which 65,565 are from advanced and 10,582 from emerging market countries.

\section{A. Leverage and debt maturity across countries and time}

Firm leverage is measured as the ratio of total debt to total assets, while debt maturity is measured as the ratio of long-term debt to total debt. ${ }^{6}$ As shown in Table 1, Panel A, firms in emerging economies exhibit a mean leverage of 0.31 , compared to a mean of 0.26 of those in advanced countries. On the other hand, firms in emerging economies have on the average 42 percent of debt in long maturity, substantially lower than the corresponding value of 55 percent for firms in advanced economies. These differences between advanced and emerging market countries persist over the sample period: As shown in Panel B, in emerging economies, the mean leverage ratio of firms is higher and debt maturity is lower than those in advanced economies in all time periods. Thus, unconditionally on firm and country characteristics, firms in emerging economies appear to carry more debt in their capital structure but with shorter maturity than firms in advanced economies.

\footnotetext{
${ }^{5}$ We exclude financial firms (2-digit SIC code 60 to 69) and utilities (2-digit SIC code 40 to 49 ), and require each firm to have at least two years of data. To remove outliers, we winsorize all firm level variables at the 0.5 and 99.5 percentiles. Advanced countries are: Australia, Austria, Belgium, Canada, Denmark, Finland, France, Germany, Greece, Hong Kong, Israel, Italy, Japan, Netherlands, New Zealand, Norway, Portugal, Singapore, Spain, Sweden, United Kingdom and United States. Emerging market countries are: Argentina, Brazil, Chile, China, Colombia, Hungary, India, Indonesia, Malaysia, Mexico, Pakistan, Peru, Philippines, Poland, Thailand, and Turkey. We categorize these countries as advanced and emerging economies according to the World Economic Outlook classification (IMF, 2006). We omit a country for a given year if that country does not have at least 10 firms for that year. As a result, we omit China in 1995, Colombia in 1995, 1996 and 2000, Israel in 1995, Peru in 1995 and 1996, and Poland in 1995, 1996 and 1997.

${ }^{6}$ Leverage is total debt (Worldscope item 03255) divided by total assets (Worldscope item 02999). Debt maturity is the ratio of long term debt to total debt. Long term debt is computed as total debt minus short term debt and current portion of long term debt (Worldscope item 03051).
} 


\section{B. The domestic financial reforms index}

To measure domestic financial reforms, we rely on the database of financial reforms of Abiad, Detragiache and Tressel (2007) (ADT henceforth). This database tracks several dimensions of financial reforms in 60 countries over the period 1973-2002. The credit controls and reserve requirements dimension accounts for the restrictiveness of reserve requirements, the existence of mandatory credit allocations set by central bank, the existence and extent of subsidized credit schemes, as well as the presence of quantitative restrictions on bank credit. The interest rate controls dimension measures the extent to which deposit and lending rates are market determined or are subject to administrative ceilings. The bank entry barriers dimension tracks entry restrictions in the banking sector and other financial sectors, including restrictions on foreign bank entry, as well as restrictions on branching and scope of bank activities. The bank privatization dimension measures the extent to which bank assets are controlled by private owners rather than the government. The securities markets dimension tracks reforms that foster the development of government and corporate bond markets as well as other financial equity markets. Finally, the bank supervision dimension considers the adoption of the Basel capital regulation and a number of characteristics of the bank supervisory system, such as the degree of independence of supervisory agency, the effectiveness of on-site and off-site examinations of banks by supervisory agency, and whether all banks are subject to supervision or not.

In each dimension, a higher score indicates a higher degree of domestic financial reforms. In the regressions, we use both indexes for the individual subcategories and an index that combines the six dimensions (domestic financial reforms (DFL) index, henceforth). The range of these indexes is between zero and one.

In the sample, there are six advanced countries (Canada, Denmark, Finland, Germany, New Zealand and Sweden) where there is no change in any dimension of the DFL index during our sample period, as by 1995 they were already quite advanced in the reforms process. In three dimensions (credit controls and reserve requirements, interest rate controls and securities markets) the main variation is in emerging economies. On the other hand, the bank privatization, bank entry and bank supervision dimensions exhibit substantial crosscountry and time variations in most countries. As shown in Table 1 and Figure 1, advanced market countries have higher scores than emerging market countries in all dimensions of the DFL index. Moreover, the DFL index has a general upward trend that flattens after 2000.

\section{Financial Openness}

To proxy access to international credit markets we use the ratio of total private sector external liabilities of the country to GDP. As noted, this measure aims at capturing de facto international financial integration as opposed to reductions in administrative barriers to capital flows. Kose, and others (2006) argue that measures of gross stocks and flows of cross-border financial claims should be used to measure financial globalization, and show that often used 
indexes of de jure liberalization of international capital flows are only marginally related to cross-border claims.

For advanced countries, the external debt liabilities of the private sector are obtained from the International Investment Position statistics of the IMF. We add together two entries, portfolio and other investment in the debt market. From this sum, we subtract the following investments of the monetary authority and the general government: bonds and notes, loans, currency and deposits, money market instruments and other liabilities of monetary authority and general government, and trade credits of general government. For emerging economies, we use data from the World Bank Global Development Finance database. We calculate the sum of private non-guaranteed long-term debt and private short-term debt. Since short-term debt data are not available solely for the private sector in this database, we assume that the ratio of short-term debt of private sector to total short-term debt is the same as the ratio of long-term debt of private sector to total long-term debt.

As shown in Figure 1, financial openness has increased over the sample period both in emerging and advanced market countries and, as the DFL index, is about constant after 2000.

\section{Methodology}

\section{A. The empirical model}

We estimate versions of the following regression models:

$$
\begin{aligned}
& L E V_{i s c t}=\alpha_{s}+\alpha_{c}+\alpha_{t}+X_{i s c t-1} \beta_{11}+Z_{c t-1} \beta_{12}+\operatorname{DFINLIB}_{c t-1} \gamma_{1}+\delta_{1} \text { FOPEN }_{c t-1}+\varepsilon_{\text {isct }} \\
& M A T_{i s c t}=\alpha_{s}+\alpha_{c}+\alpha_{t}+X_{\text {isct }-1} \beta_{21}+Z_{c t-1} \beta_{22}+\operatorname{DFINLIB}_{c t-1} \gamma_{2}+\delta_{2} \text { FOPEN }_{c t-1}+\theta L E V_{\text {isct }-1}+\eta_{\text {isct }}
\end{aligned}
$$

where $L E V_{\text {isct }}$ and $M A T_{\text {isct }}$ denote leverage and debt maturity of firm $i$ belonging to industry $s$ in country $c$ and year $t$. The terms $\alpha_{s}, \alpha_{c}$ and $\alpha_{t}$ denote industry (2-digit SIC codes), country and time fixed effects, respectively. The terms $X_{\text {isct-1 }}$ and $Z_{c t-1}$ denote lagged vectors of firm-level and country-level control variables respectively, DFINLIB $_{c t-1}$ is the lagged DFL index or the set of its components, and FOPEN $N_{c t-1}$ is the lagged value of our proxy measure of financial openness.

Using lagged variables is consistent with the idea that firms' debt financing decisions in any given period are made conditional on values of all variables at the beginning of that period. In the debt maturity regressions, we also introduce the lagged level of leverage as an additional control, since firms' debt maturity decisions likely depend on total indebtedness in the previous period. All standard errors are clustered by country. 
We present results for three key regression specifications applied to the full sample, as well as to the samples of developed and emerging market countries separately. All specifications include industry, country and time fixed effects, which control for time invariant industry and country-specific characteristics, and for a common time effects across countries. Subsequently, we report the results for a set of alternative specifications as robustness tests, including one with firm fixed effects.

In the first specification, we include firm-specific variables, the index of domestic financial reforms and financial openness, and control for a number of country-level covariates. These regressions allow us to assess the overall impact of domestic financial reforms and international financial openness (coefficients $\gamma$ and $\delta$ ) conditional on a large set of firm-specific and country-specific characteristics. The second specification is the same as the first except that we replace the domestic financial reforms index with its components entered separately. This allows us to detect possibly differential effects of each dimension of domestic financial reforms on leverage and debt maturity.

\section{B. Firm level controls}

Corporate finance theory identifies growth opportunities, size, profitability, tangibility, asset maturity, and asset volatility as key determinants of firms' leverage and debt maturity (see Harris and Raviv (1991) and Rajan and Zingales (1995) for leverage and Barclay and Smith (1995) and Stohs and Mauer (1996) for debt maturity). ${ }^{7}$ Our proxy measures of these determinants are constructed consistent with the empirical corporate finance literature.

Growth opportunities are measured by Tobin’s Q, firm size by the log value of endperiod total assets, profitability by the ratio of earnings before interest and taxes (EBIT) to total assets, asset tangibility by the ratio of net plant, property and equipment (NPPE) divided by total assets, asset maturity by a ratio similar to that used by Barclay, Marx, and Smith (2003), and asset volatility by stock return volatility. ${ }^{8}$

In the leverage regressions, the vector of firm level variables includes firm size, growth opportunities, profitability and tangibility as in Rajan and Zingales (1995). In addition,

\footnotetext{
${ }^{7}$ We are unable to account for taxation and its role in determining debt financing decisions due to data unavailability.

${ }^{8}$ Tobin's Q is calculated as the sum of year end market capitalization (year end market price multiplied by common shares outstanding) (Worldscope item 08001) and total debt, divided by total assets. EBIT is Worldscope item 18191, while net plant, property and equipment (NPPE) is Worldscope item 02501. For asset maturity, we use the formula: Asset maturity = (current assets/total assets)*(current assets/net sales)+(NPPE/total assets)* (NPPE/ depreciation, depletion and amortization). We use net sales instead of cost of goods sold, ,since cost of goods sold data are not as widely available as sales data for international firms. Current assets, net sales, and depreciation, depletion and amortization are Worldscope items 02201, 01001, and 01151, respectively. Stock returns volatility is the annualized standard deviation of weekly returns over a year.
} 
we include lagged dummy variables indicating whether a firm has either a bond rating from Moody's or it has issued ADRs in a given year, since the leverage of rated firms with access to international capital markets may significantly differ from that of firms without these characteristics. ${ }^{9}$ In the debt maturity regressions, we follow Barclay and Smith (1995), Stohs and Mauer (1996), Fan, Titman and Twite (2006) and SV by including firm size, growth opportunities, asset maturity, asset volatility, tangibility, profitability, leverage, as well as bond ratings and ADR dummies. Bond ratings and ADR dummies account for the possibility of distinct debt maturity choices for firms with access to international capital markets. SV find that these firms have higher leverage and longer debt maturity than those that do not have access to international capital markets.

\section{Country-level controls}

Country-specific characteristics are controlled by a set of macroeconomic variables and other proxies of institutional characteristics. Time fixed effects are introduced to control for worldwide developments, both long-term and cyclical, as well as for events that affected world financial markets, such as the Asian and Russian crises.

The level of country's development is measured by the natural logarithm of gross domestic product (GDP) per capita at purchasing power parity (PPP) from the World Development Index (World Bank) database. Cross-country differences in the macroeconomic environment are accounted for by GDP growth, a proxy measure of volatility of GDP growth, the annual inflation rate and a high inflation dummy, the latter being introduced to take possible non-linearities into account. ${ }^{10}$

The liquidity of the domestic stock market can be important in influencing firms' debt financing decisions. To the extent that long-term debt and equity are substitutes, firms operating in more liquid markets, in comparison with their peers in countries with less liquid stock markets, are likely able to more easily substitute equity for long-term debt, and carry relatively more short-term debt. Lastly, we control for banking crises, since the supply of bank credit to the corporate sector typically shrinks during these episodes, likely affecting firms’ leverage and debt maturity. We use Harvey's country risk chronology to determine

\footnotetext{
${ }^{9}$ We identify firms that have issued ADRs and have bond ratings for each firm-year, and constructed relevant dummies. In our sample, there are 3060 firm-year observations with ADRs and 6808 firm-year observations with a bond rating from Moody's. Data on stock returns and ADRs are from Datastream. We utilize Mergent Online to identify firms with a bond rating in any given year.

${ }^{10}$ GDP growth volatility is measured as the standard deviation of GDP growth over five years. The high inflation dummy is set to 1 in a given year for a given country if that country has inflation above the sample median in that year.
} 
banking crisis dates, and construct a banking crisis dummy, which is set to 1 for the year after the country is classified as being in a crisis. ${ }^{11}$

\section{The Results}

\section{A. Leverage, debt maturity and firm characteristics}

As shown in Table 2, the results on the firm specific determinants of leverage are consistent with the existing literature. Leverage is positively and significantly related to firm size, tangibility, and the existence of a bond rating. ${ }^{12}$ This result indicates that larger (and rated) firms with more tangible assets are able to borrow at more favorable terms because of their better ability to offer providers of finance verifiable collateral relative to smaller (and unrated) firms with less tangible assets. On the other hand, leverage is negatively and significantly related to growth opportunities owing to the underinvestment problem identified by Myers (1977), and to profitability, consistent with previous empirical findings. ${ }^{13}$ Note also that leverage is higher for firms that have issued ADRs, suggesting that these firms can more easily raise debt when they also raise equity in the U.S.

Turning to the debt maturity regressions presented in Table 3, debt maturity is positively related to leverage, size, asset maturity, tangibility, profitability, the presence of a bond rating and of an ADR program, and negatively related to volatility. The coefficients of asset maturity, the presence of an ADR program and volatility are not statistically significant in emerging economies. These findings are broadly consistent with the existing theoretical and empirical literature on debt maturity. Specifically, debt maturity is positively related to leverage because higher leverage increases the liquidity risk associated with the rollover of short-term debt. Maturity is also increasing in firm size since there are fixed costs to issuing long-term bonds and because large firms are less affected by information asymmetries. There is a positive relation between debt maturity and asset maturity as firms attempt to match the maturities of assets and liabilities. This relation, however, is insignificant in emerging economies suggesting that the ability of firms in emerging economies to match the maturities of their assets and liabilities is more limited than that of firms in advanced countries. Debt maturity is positively related to tangibility since assets whose value can be more easily priced can be used more readily as collateral, reducing the cost of borrowing long term. Debt maturity is also increasing with firm profitability, as more profitable firms are better able to

\footnotetext{
${ }^{11}$ The country risk chronology is available at: http://www.duke.edu/ charvey/Country risk/chronology.

${ }^{12}$ Note that the coefficient of the bond rating for emerging economies regressions is positive but not significant, likely owing to the low number of firms with a bond rating in the emerging economies sample.

${ }^{13}$ Alternative theories have opposite predictions about the leverage-profitability relationship. According to the pecking order theory, the relationship is negative as firms prefer to use internal finance when available. According to the tradeoff theory, the expected sign is positive, since profitable firms issue more debt to benefit from its tax advantages.
} 
commit to long-term interest payments; and with bond rating and ADRs, due to easier access to long-maturity bond and equity markets, respectively. Finally, debt maturity is negatively related to volatility as increased business risk increases the cost of borrowing long term. ${ }^{14}$

The only finding that appears at variance with theoretical predictions is that debt maturity is increasing in growth opportunities (although the effect is marginally significant in emerging economies). Although the underinvestment problem of Myers (1977) suggests that debt maturity should decrease with growth opportunities, the empirical findings of SV and Fan, Titman and Twite (2006) are in line with our findings. With respect to profitability, our evidence indicates a positive relation between debt maturity and profitability, consistent with the results in Demirgüç-Kunt and Maksimovic (1999) and Fan, Titman and Twite (2006). ${ }^{15}$

To summarize, we find strong evidence that firm characteristics that have been found to affect leverage and debt maturity in the existing literature are also relevant for the firms in our sample.

\section{B. The impact of some country specific characteristics}

Identifying the impact of financial reforms and financial openness on firm leverage and debt maturity requires that we control for changes in country characteristics and the macroeconomic environment. Thus, our regressions include proxies for countries' level of development, their macroeconomic environment, the degree of liquidity of their stock markets, and the occurrence of banking crises, in addition to including the DFL index and our measure of financial openness as explanatory variables.'

In the leverage regressions presented in Table 2, leverage is positively associated with GDP per capita, suggesting that the higher level of development of financial markets and intermediaries in more developed economies is likely to foster firms' reliance on debt. GDP growth has a negative coefficient, indicating that leverage moves countercyclically. This result is consistent with the predictions of the model of Hackbarth, Miao and Morellec (2006), and with the evidence reported in Korajczyk and Levy (2003) that in periods of rapid growth firms rely more on internal finance. Leverage is also negatively related to GDP volatility and inflation, indicating that an uncertain macroeconomic environment makes it more difficult for firms to borrow. Finally, leverage is lower when the stock market is more liquid, as firms may find it relatively less expensive to rely on equity financing. In emerging economies, disruptions in the banking system associated to banking crises also result in lower leverage (there are no crises in advanced countries during our sample period). All in all, the impact of these country-level characteristics on leverage is consistent with theory and existing evidence.

\footnotetext{
${ }^{14}$ For details, see Barclay and Smith (1995), Stohs and Mauer (1996), Demirguc-Kunt and Maxsimovic (1999), Gianetti (2003), and SV.

${ }^{15}$ However, this relation is found to be negative in SV.
} 
In the debt maturity regressions, the country-level controls have similar signs as in the leverage regressions for advanced economies, with inflation, GDP growth, GDP volatility and stock market liquidity being negatively related to debt maturity (Table 3). In emerging economies, GDP per capita and the high inflation dummy are negatively related to debt maturity, while the other macroeconomic variables are not significant.

In sum, these results indicate the importance of including a rich set of countryspecific characteristics in any specification of a statistical model of firms' financing patterns.

\section{The impact of domestic financial reforms and international financial openness}

Turning to the main variables of interest, openness and reforms, we find important similarities as well as differences between firms' financing patterns in advanced and emerging economies. In advanced economies, both leverage and debt maturity are positively and significantly related to international financial openness and domestic financial reforms. This indicates that, in these countries, increased openness of financial markets and deregulation have likely increased the availability and reduced the relative cost of debt finance in general, and of long-term debt finance in particular. ${ }^{16}$

The picture is more complex when we turn to emerging economies. In these countries, as in the advanced economies, leverage is positively and significantly related to financial openness, indicating increased access to debt finance as expected. However, leverage is negatively related to domestic financial reforms and, contrary to what found in advanced economies, increased financial openness decreases debt maturity. The overall index of domestic financial reforms has no significant effect on debt maturity in these markets. Thus, in emerging economies, stronger integration in international financial market seems to have increased the availability and reduced the relative cost of debt finance, but the additional financing has been provided at short maturity. On the other hand, domestic financial deregulation appears to make debt financing less attractive to emerging market corporations, even though these reforms were aimed at improving the functioning of credit markets.

These results indicate that the relative strength of demand and supply shifts induced by increased international financial openness and domestic financial reforms critically depends on "structural" country characteristics. Specifically, the importance of cross-country differences in the intensity of information asymmetries and the cost of financial contracting (poor corporate governance and accounting standards, weak creditor rights, etc.) stressed by Diamond (2004) and Stulz (2005) may explain the different impact of financial openness on

\footnotetext{
${ }^{16}$ We should note that this is not simply the outcome of the general decline of interest rates in all countries during the period examined, since such a common downward trend in interest rates is captured by time fixed effects. We also control for short-term interest rates for robustness and the results are comparable to those reported.
} 
debt maturity. If the provision of short-term funds is used by banks and investors as a monitoring device of borrowers located in an environment less well-known and characterized by a weak financial infrastructure, and such environment is also one where firms find it more difficult or costlier to access to alternative sources of funding, then the supply of short-term funding relative to the total may increase. In addition, more bank competition may break down old relationships, and at the beginning of new relationships banks may lend proportionally more on a short-term basis. This environment may be one characterizing an emerging market experiencing financial globalization and domestic deregulation, at least in a transitory phase. By contrast, in a developed economy, none of these conditions may be crucial, and the increased entry and openness may induce firms to increase their supply of long-term debt instruments as a larger variety of financing sources becomes available. With regard to reforms, similar forces appear at play.

In the next section, we consider specific financial reforms separately to gain a better understanding on which specific reforms may be driving the results.

\section{Disentangling the effects of financial reforms}

In the second specification reported in Table 2 and Table 3, we rerun the regression after breaking down the DFL index to its components. In interpreting the results, it is important to keep in mind that, as explained in section III, for three of the components (credit allocation and reserve requirements, interest rate controls and securities market) the sample variation is very limited in advanced countries, so the full sample results are driven mainly by emerging economies. In addition, to the extent that reforms take place at the same time, there may be multicollinearity among the components of the index, which may lower the significance of individual coefficients.

The main findings are summarized in the table below. The negative effect of financial reforms on leverage in emerging economies is driven by most of the components, with the exception of credit allocation (which is not significant) and of bank privatization (which has a positive and significant impact). Thus, measures to facilitate entry in the banking sector, interest rate liberalization, stronger supervision, and reforms to develop securities markets, all seem to have increased the cost or reduced the availability of debt finance for corporations in emerging economies relative to other sources of finance. The development of domestic securities markets, on the other hand, seems to have helped lengthening debt maturity, perhaps because this variable captures mainly progress in establishing long-term domestic currency government bond markets, which, in turns, helps investors pricing long-term corporate debt. 


\section{The impact of financial reforms components on leverage and debt maturity}

Reforms with coefficients with $p$ value $<=0.10$

\begin{tabular}{|c|c|c|}
\hline Countries & LEVERAGE & DEBT MATURITY \\
\hline ADVANCED & $\begin{array}{l}\text { Bank entry + } \\
\text { Credit allocation + } \\
\text { Interest rates - } \\
\text { Supervision - } \\
\text { Bank Privatization + }\end{array}$ & $\begin{array}{l}\text { Interest rates }+ \\
\text { Supervision }+ \\
\text { Bank Privatization }+\end{array}$ \\
\hline EMERGING & $\begin{array}{l}\text { Bank entry - } \\
\text { Interest rates - } \\
\text { Securities markets - } \\
\text { Supervision - } \\
\text { Bank Privatization + }\end{array}$ & $\begin{array}{l}\text { Securities }+ \\
\text { Bank Privatization - }\end{array}$ \\
\hline
\end{tabular}

In advanced economies, reforms to strengthen supervision and liberalization of interest rates are associated with less leverage and longer debt maturity, suggesting that they may have induced banks to tighten their lending standards. Bank privatization increases leverage in all countries, but the effects on maturity differ: they are positive in advanced economies and negative in emerging economies. This may reflect the fact that in emerging economies stateowned banks are heavily involved in policy lending, which is typically at long maturities, while in advanced economies state banks are less encumbered with developmental tasks.

With the important exception of bank privatization, the impact of domestic financial reforms on leverage in emerging economies is negative, while it is positive in advance countries. Factors similar to those explaining the differential impact of financial openness on debt maturity may be at play, i.e. in emerging economies the weight of informational asymmetries and relatively less developed market infrastructure may have induced providers of finance to tighten their lending standard and charge higher risk premia, with firms responding by relying less on debt relative to equity or internal funds.

\section{E. Financial Constraints}

Next, we consider whether the impact of financial reforms and financial openness on firms' leverage and debt maturity is different for firms that are potentially facing financial constraints and firms that are not. ${ }^{17}$ Other things being equal, if domestic financial reforms and international financial openness increase the availability of funds, especially long-term credit, and decrease their cost owing to more competition among providers of finance, then

\footnotetext{
${ }^{17}$ The literature has studied how monetary and cyclical conditions influence access to credit depending on whether firms are financially constrained or not. Using firm size as a proxy for financial constraints, Gertler and Gilchrist (1993) find that short-term lending during tight monetary conditions increases for large firms but contracts for small firms, suggesting that small firms may become credit constrained during monetary tightening. Korajczyk and Levy (2003) find that unconstrained firms increase leverage during expansions, suggesting that they are able to time debt issuance to take advantage of more favorable market conditions.
} 
firms' financial constraints should be reduced. Thus, we should find that reforms and openness have stronger impact on the leverage and debt maturity of constrained firms. If, instead, financial constraints bind due to the presence of information asymmetries, governance opaqueness and weak creditors' rights, rather than the restrictions on entry or on the activities of providers of finance, then we may not observe this effect. Therefore, the following tests provide further evidence on the differential firm response to openness and reforms.

Following Korajczyk and Levy (2003), we define a firm in a given country in a given year as constrained if it is not paying dividend and its Tobin's $Q$ is either greater than 1 or greater than the median for that country. Using this definition, 22 percent of our sample observations are classified as constrained. ${ }^{18}$ The regression results are given in Table 4. Panel A and Panel B report results on leverage and debt maturity, respectively, for advanced countries and emerging economies. We should first note that, consistent with Korajczyk and Levy (2003), we find that macroeconomic conditions mainly affect leverage decisions of unconstrained firms.

A comparison of the size and sign of the coefficients of openness and reforms in the leverage regressions show that, in advanced economies, the positive effect of these variables is stronger for constrained firms. As noted, this result is consistent with an increase in competition among providers of credit, both domestically and internationally, making financial constraints less severe. Interestingly, when we disaggregate the reform index, it appears that stronger supervision has asymmetric effects: while constrained firms benefits (in the form of increased leverage), unconstrained firms suffer (and reduce leverage). For debt maturity, on the other hand, more openness tends to increase maturity, but only for unconstrained firms, while the effect of financial reforms seems more pronounced in the constrained sample.

In emerging economies, the positive effect of openness on leverage is stronger for unconstrained firms than for constrained firms. This result is consistent with the view that financial constraints for emerging market firms arise from informational asymmetries and governance opaqueness, rather than from limited competition or excessive regulation among funds' providers. With regard to financial reforms index, we do not find differential effects between constrained and unconstrained firms. Bank privatization, however, has opposite effects on the two types of firms: it lowers leverage in constrained firms, but increases it in unconstrained firms. This may be because constrained firms are the main beneficiaries of loans from state-owned banks. Deregulation of restrictions on bank entry leads to lower

\footnotetext{
${ }^{18}$ Observations in which firms were paying dividends account for 57.1 percent of the sample. We have 15,808 observations in the constrained sample (14,120 from advanced economies and 1688 from emerging economies) and 55,607 observations in the unconstrained sample (47,277 from advanced economies and 8,330 from emerging economies).
} 
corporate leverage, but the effect is quantitatively stronger for constrained firms, perhaps because these firms were more reliant on relationship lending which may be disrupted by new entry. Privatization and bank entry deregulation also result in sharper reduction in debt maturity in constrained firms than in unconstrained firms in emerging economies. The effect of bank supervision on leverage in emerging economies is similar to that in advanced countries (positive, although not significant, for constrained and negative for unconstrained firms).

In sum, this evidence supports our previous results regarding the differential impact of reforms and openness on firms' financing patterns as mainly due to cross-country differences in the quality of countries' financial infrastructure.

\section{F. Robustness}

To test the robustness of our findings, we re-estimate the regressions using firm fixed effects rather than country and industry fixed effects, and find that the signs and significance levels of the coefficients of the variables of interest remain unchanged. The results are reported in Table 5 and Table 6.

We carry out a battery of robustness tests with an additional set of country-specific variables that have been considered as important determinants of firms' debt financing decisions. This set includes the International Country Risk Guide (ICRG) composite index for the country risk, which embeds economic as well as institutional and political country characteristics, a proxy measure of the depth of the banking sector, and an indicator of creditor rights. ${ }^{19}$ The results are reported in Table 5 and Table 6 . The findings are largely in line with those reported in Table 2 and Table 3. Additionally, these results suggest that firms in emerging market countries with high country risk carry less leverage and have shorter debt maturity. Countries with strong creditor rights have more leverage, but with longer maturity in advanced and shorter maturity in emerging economies. ${ }^{20}$

\footnotetext{
${ }^{19}$ To proxy the depth of a banking sector we use the ratio of private credit by deposit money banks to GDP taken from the Financial Structure Dataset of Beck and Al-Hussainy (World Bank, February 2006). To capture cross-country differences in creditor rights, we use the creditor rights index of Djankov, McLiesh and Shleifer (2007), which is similar to that of La Porta, and others (1998). It combines four dimensions of creditor rights over the period 1978-2003. These dimensions are restrictions on reorganization, the existence of automatic stay or asset freeze, priority of payment for secured creditors, and management of the firm during reorganization. The creditor rights index varies between 0 and 4 . The higher is the score, the stronger are the creditor rights.

${ }^{20}$ In an additional robustness test, we also control for the slope of the yield curve using the spread between 10year and 2-year swap rates. Long-term swap rates are available mainly for advanced economies. Therefore we run these regressions for the overall sample and advanced market sample. We find that the slope of the yield curve does not affect leverage but increases debt maturity. This is consistent with the view , in line with that issuing long term debt reduces firm's expected tax liability and increases firm value when the yield curve is upward sloping (Brick and Ravid, 1985). The results are comparable to those reported and are available from authors upon request.
} 
Finally, recall that one of the main findings in SV is that financial sector reforms in emerging economies have differential effects on firms that access global capital markets and firms that do not. To test whether this is the case in our sample, we interact the financial openness and domestic financial reforms index with the ADR and bond rating dummy variables. The results are reported in Table 5. Our evidence does not suggest any significant differential effects for firms that have access to global markets. The only significant finding is that firms with bond ratings in advanced economies with more financial openness carry longer maturity debt.

\section{CONCLUSION}

The supply of finance to corporations has undergone broad changes in the last decades both in advanced and emerging economies. In particular, thanks to technological changes and policies to reduce administrative barriers, corporations in many countries around the world have increased access to foreign sources of finance. On the domestic front, banking sectors have been deregulated along several dimensions: controls on interest rates have been removed, mandates on credit allocation reduced or lifted, many state-owned banks have been privatized, policies to strengthen the development of bond and stock markets and to improve bank supervision and regulation have been undertaken. In this paper, we trace out how some of these transformations have changed the way in which corporations use debt financing.

To explore this issue, we rely on a large cross-country panel of data and novel, timevarying measures of international financial openness and domestic financial reforms. This helps us address some well-known difficulties in identifying the effects of institutional changes on economic variables. First, there is the possibility that the effects attributed to institutions are due to omitted, time-invariant country characteristics. In our study, the effects of financial openness and reforms on firm leverage and debt maturity are entirely driven by within-country, time-series changes in the institutional characteristics of interest, not by crosscountry effects. A second common difficulty is that sometimes several institutional reforms happen at the same time, and thus it is difficult to identify the effects of an individual policy change. By relying on a comprehensive measure of financial reforms that tracks reforms on several different fronts, we are able to minimize this type of concern. Third, the impact of financial reforms and openness on debt financing decisions can be different for financially constrained and unconstrained firms. By examining these two types of firms separately, we are able to discover whether there is a differential impact.

We find that an increase in international financial openness and domestic deregulation leads to higher leverage and longer debt maturity in advanced economies, the more so in financially constrained firms. This is consistent with the view that these transformations have helped reduce the cost of debt finance - especially long-term debt finance - , and have increased its availability. In emerging economies, improved access to international credit 
markets increases leverage, but is associated with a shortening of debt maturity. In addition, financial reforms lead firms, particularly financially constrained ones, to reduce leverage and borrow at shorter maturity. Bank privatization and bank entry deregulation seem to be the reforms driving these effects.

These findings suggest that in emerging markets fundamental weaknesses in the institutional environment, such as weak law and contract enforcement, vague property rights, poor accounting standards, may make it difficult for firms to benefit from credit market deregulation and increased international financial openness. The task of the next generation of reforms might well be to make progress in improving the underlying institutional environment. 


\section{Table 1}

\section{Descriptive Statistics}

This table provides descriptive statistics for the variables in the sample of advanced countries and emerging countries as well as the overall sample. The sample covers 22 advanced and 16 emerging economies over the period 1994-2002. Panel A reports mean, median and standard deviation of the variables as well as the number of firm-year observations over the sample period 1994-2002. Panel B reports the mean levels of leverage, debt maturity, financial openness, financial liberalization index and its components yearly from 1995 to 2002. Firm level variables are as follows: Leverage is the ratio of total debt to total assets; debt maturity is the ratio of longterm debt to total debt; growth opportunities are measured as the ratio of market value of assets to book value of assets; size is natural logarithm of total assets; asset maturity is measured similar to that of Barclay, Marx and Smith (2003); tangibility is the ratio of net plant property and equipment to total assets; profitability is EBIT divided by total assets; volatility is stock return volatility computed over the year using weekly returns. Country level variables are as follows: Share turnover is the share turnover of all stocks in a country; inflation is measured as the natural logarithm of one plus the annual change in consumer prices; GDP per capita is measured as the natural logarithm GDP per capita at purchasing power parity; GDP growth is the annual change of GDP per capita; growth volatility is measured as the standard deviation of GDP growth over five years. Other country level variables are financial openness measured as the external private sector debt to GDP. Financial liberalization index and its components (bank entry, credit controls, securities markets, interest rates and bank privatization) are from Abiad, Detragiache and Tressel (2006). Number of firm year observations with ADRs and bond rating are also reported. Sample is winsorized at $0.5 \%$ levels of the tails of the distribution.

Panel A: Overall Sample Period

\begin{tabular}{|c|c|c|c|c|c|c|c|c|c|}
\hline & \multicolumn{3}{|c|}{ All sample } & \multicolumn{3}{|c|}{ Advanced } & \multicolumn{3}{|c|}{ Emerging } \\
\hline & Mean & Median & Std.dev & Mean & Median & Std.dev & Mean & Median & Std.dev \\
\hline Leverage & 0.268 & 0.246 & 0.194 & 0.261 & 0.238 & 0.191 & 0.313 & 0.299 & 0.207 \\
\hline Debt Maturity & 0.533 & 0.569 & 0.340 & 0.551 & 0.594 & 0.339 & 0.422 & 0.426 & 0.324 \\
\hline Growth Opportunities & 1.293 & 0.876 & 1.380 & 1.334 & 0.894 & 1.437 & 1.042 & 0.782 & 0.930 \\
\hline Size & 13.554 & 13.146 & 3.096 & 13.312 & 12.825 & 3.082 & 15.002 & 14.715 & 2.704 \\
\hline Asset Maturity & 5.058 & 2.595 & 8.576 & 4.451 & 2.319 & 7.682 & 8.755 & 5.141 & 12.094 \\
\hline Tangibility & 0.332 & 0.296 & 0.219 & 0.315 & 0.276 & 0.215 & 0.439 & 0.431 & 0.212 \\
\hline Profitability & 0.002 & 0.055 & 0.275 & 0.002 & 0.051 & 0.292 & 0.056 & 0.057 & 0.111 \\
\hline Volatility & 0.564 & 0.469 & 0.353 & 0.566 & 0.463 & 0.364 & 0.551 & 0.501 & 0.281 \\
\hline Share Turnover & 96.351 & 77.300 & 57.348 & 101.105 & 84.600 & 55.664 & 67.401 & 44.590 & 58.925 \\
\hline Inflation & 0.026 & 0.021 & 0.049 & 0.017 & 0.019 & 0.016 & 0.078 & 0.046 & 0.112 \\
\hline GDP per Capita & 9.989 & 10.194 & 0.636 & 10.224 & 10.205 & 0.169 & 8.556 & 8.760 & 0.549 \\
\hline GDP growth & 0.018 & 0.022 & 0.025 & 0.017 & 0.021 & 0.020 & 0.021 & 0.028 & 0.045 \\
\hline Growth volatility & 0.019 & 0.014 & 0.020 & 0.016 & 0.013 & 0.017 & 0.037 & 0.026 & 0.026 \\
\hline Financial openness & 0.672 & 0.439 & 0.678 & 0.753 & 0.462 & 0.699 & 0.197 & 0.190 & 0.143 \\
\hline Financial liberalization & 0.850 & 0.909 & 0.136 & 0.894 & 0.909 & 0.065 & 0.608 & 0.562 & 0.139 \\
\hline Bank entry & 0.900 & 1.000 & 0.203 & 0.933 & 1.000 & 0.162 & 0.699 & 0.667 & 0.293 \\
\hline Credit controls & 0.654 & 0.750 & 0.161 & 0.689 & 0.750 & 0.113 & 0.441 & 0.500 & 0.229 \\
\hline Securities markets & 0.951 & 1.000 & 0.129 & 1.000 & 1.000 & & 0.656 & 0.667 & 0.127 \\
\hline Bank supervision & 0.807 & 1.000 & 0.244 & 0.859 & 1.000 & 0.203 & 0.491 & 0.333 & 0.231 \\
\hline Interest rates & 0.970 & 1.000 & 0.127 & 0.997 & 1.000 & 0.033 & 0.811 & 1.000 & 0.278 \\
\hline \multirow[t]{2}{*}{ Bank privatization } & 0.796 & 1.000 & 0.298 & 0.857 & 1.000 & 0.235 & 0.427 & 0.330 & 0.367 \\
\hline & \multicolumn{3}{|c|}{ No of observations } & \multicolumn{3}{|c|}{ No of observations } & \multicolumn{3}{|c|}{ No of observations } \\
\hline Total & \multicolumn{3}{|c|}{76147} & \multicolumn{3}{|c|}{65565} & \multicolumn{3}{|c|}{10582} \\
\hline With ADR & \multicolumn{3}{|c|}{3060} & \multicolumn{3}{|c|}{2494} & \multicolumn{3}{|c|}{566} \\
\hline With Bond Rating & \multicolumn{3}{|c|}{6808} & \multicolumn{3}{|c|}{6646} & \multicolumn{3}{|c|}{162} \\
\hline
\end{tabular}


Table 1-continued

Panel B: Time Series

\begin{tabular}{|c|c|c|c|c|c|c|c|c|c|}
\hline & 1994 & 1995 & 1996 & 1997 & 1998 & 1999 & 2000 & 2001 & 2002 \\
\hline \multicolumn{10}{|l|}{ Leverage } \\
\hline All sample & 0.242 & 0.249 & 0.254 & 0.267 & 0.281 & 0.283 & 0.270 & 0.267 & 0.265 \\
\hline Advanced & 0.236 & 0.242 & 0.242 & 0.254 & 0.270 & 0.277 & 0.264 & 0.262 & 0.261 \\
\hline Emerging & 0.282 & 0.299 & 0.315 & 0.350 & 0.348 & 0.322 & 0.310 & 0.300 & 0.286 \\
\hline \multicolumn{10}{|l|}{ Debt maturity } \\
\hline All sample & 0.590 & 0.575 & 0.577 & 0.557 & 0.556 & 0.547 & 0.525 & 0.500 & 0.500 \\
\hline Advanced & 0.612 & 0.596 & 0.601 & 0.576 & 0.579 & 0.565 & 0.540 & 0.517 & 0.517 \\
\hline Emerging & 0.461 & 0.430 & 0.444 & 0.443 & 0.429 & 0.433 & 0.429 & 0.399 & 0.405 \\
\hline \multicolumn{10}{|c|}{ Financial openness } \\
\hline All sample & 0.464 & 0.490 & 0.514 & 0.563 & 0.602 & 0.630 & 0.743 & 0.759 & 0.783 \\
\hline Advanced & 0.516 & 0.540 & 0.581 & 0.628 & 0.666 & 0.699 & 0.824 & 0.854 & 0.889 \\
\hline Emerging & 0.128 & 0.169 & 0.175 & 0.194 & 0.259 & 0.218 & 0.199 & 0.191 & 0.175 \\
\hline \multicolumn{10}{|c|}{ Financial liberalization } \\
\hline All sample & 0.792 & 0.811 & 0.818 & 0.827 & 0.835 & 0.864 & 0.871 & 0.862 & 0.860 \\
\hline Advanced & 0.832 & 0.853 & 0.876 & 0.879 & 0.883 & 0.907 & 0.910 & 0.904 & 0.904 \\
\hline Emerging & 0.514 & 0.528 & 0.503 & 0.539 & 0.559 & 0.589 & 0.609 & 0.609 & 0.610 \\
\hline \multicolumn{10}{|c|}{ Banking sector entry } \\
\hline All sample & 0.694 & 0.696 & 0.795 & 0.830 & 0.822 & 0.957 & 0.965 & 0.961 & 0.958 \\
\hline Advanced & 0.703 & 0.708 & 0.832 & 0.859 & 0.845 & 0.993 & 0.999 & 0.998 & 0.998 \\
\hline Emerging & 0.630 & 0.616 & 0.594 & 0.656 & 0.690 & 0.730 & 0.739 & 0.733 & 0.724 \\
\hline \multicolumn{10}{|l|}{ Credit controls } \\
\hline All sample & 0.872 & 0.656 & 0.643 & 0.637 & 0.658 & 0.661 & 0.664 & 0.654 & 0.652 \\
\hline Advanced & 0.921 & 0.691 & 0.703 & 0.684 & 0.688 & 0.689 & 0.692 & 0.685 & 0.685 \\
\hline Emerging & 0.535 & 0.421 & 0.319 & 0.345 & 0.487 & 0.487 & 0.474 & 0.463 & 0.457 \\
\hline \multicolumn{10}{|c|}{ Securities markets } \\
\hline All sample & 0.949 & 0.949 & 0.935 & 0.952 & 0.950 & 0.955 & 0.957 & 0.953 & 0.952 \\
\hline Advanced & 1.000 & 1.000 & 1.000 & 1.000 & 1.000 & 1.000 & 1.000 & 1.000 & 1.000 \\
\hline Emerging & 0.602 & 0.605 & 0.586 & 0.656 & 0.664 & 0.668 & 0.666 & 0.672 & 0.671 \\
\hline \multicolumn{10}{|c|}{ Bank supervision } \\
\hline All sample & 0.707 & 0.722 & 0.730 & 0.743 & 0.819 & 0.836 & 0.846 & 0.829 & 0.831 \\
\hline Advanced & 0.788 & 0.790 & 0.813 & 0.800 & 0.880 & 0.888 & 0.888 & 0.871 & 0.873 \\
\hline Emerging & 0.159 & 0.258 & 0.277 & 0.397 & 0.474 & 0.507 & 0.558 & 0.579 & 0.587 \\
\hline \multicolumn{10}{|l|}{ Interest rate } \\
\hline All sample & 0.974 & 0.978 & 0.964 & 0.966 & 0.955 & 0.969 & 0.979 & 0.972 & 0.974 \\
\hline Advanced & 0.994 & 0.994 & 0.991 & 0.989 & 0.989 & 1.000 & 1.000 & 1.000 & 1.000 \\
\hline Emerging & 0.836 & 0.866 & 0.822 & 0.823 & 0.760 & 0.777 & 0.835 & 0.804 & 0.820 \\
\hline \multicolumn{10}{|c|}{ Bank privatization } \\
\hline All sample & 0.789 & 0.786 & 0.791 & 0.795 & 0.770 & 0.800 & 0.814 & 0.798 & 0.798 \\
\hline Advanced & 0.844 & 0.844 & 0.859 & 0.855 & 0.851 & 0.861 & 0.869 & 0.853 & 0.855 \\
\hline Emerging & 0.404 & 0.390 & 0.425 & 0.431 & 0.304 & 0.413 & 0.438 & 0.467 & 0.470 \\
\hline \multicolumn{10}{|l|}{$\begin{array}{l}\text { Number of } \\
\text { observations }\end{array}$} \\
\hline All sample & 4732 & 5130 & 5767 & 7299 & 7400 & 8975 & 10718 & 12644 & 13482 \\
\hline Advanced & 4168 & 4493 & 4887 & 6282 & 6299 & 7746 & 9348 & 10846 & 11496 \\
\hline Emerging & 564 & 637 & 880 & 1017 & 1101 & 1229 & 1370 & 1798 & 1986 \\
\hline
\end{tabular}




\section{Table 2}

\section{Leverage, Financial Openness and Financial Liberalization}

This table shows: (1) how financial liberalization and financial openness affect leverage, controlling for the macroeconomic and firm level factors; and (2) how the six dimensions of financial liberalization (bank entry, credit control, interest rates, securities markets, bank supervision and privatization) affect leverage, controlling for financial openness, firm level factors and macroeconomic factors. The sample covers the period 1994-2002 for 22 advanced and 16 emerging countries. Variable definitions are given in Table 1. All independent variables are lagged by one period. Industry, country and year dummies are controlled. Standard errors are clustered by country. The labels $^{\text {a,b, c }}$ denote significance at the $1 \%, 5 \%$, and $10 \%$ level, respectively and t-statistics are given in italics.

\begin{tabular}{|c|c|c|c|c|c|c|}
\hline \multirow{3}{*}{ Intercept } & \multicolumn{3}{|c|}{ (1) } & \multicolumn{3}{|c|}{ (2) } \\
\hline & All sample & Advanced & Emerging & All sample & Advanced & Emerging \\
\hline & $-1.714^{\mathrm{a}}$ & $-3.231^{\mathrm{a}}$ & $-1.565^{\mathrm{a}}$ & $-1.17^{\mathrm{a}}$ & $-3.075^{\mathrm{a}}$ & -0.758 \\
\hline & -5.6 & -5.88 & -3.34 & -3.61 & -4.8 & -1.49 \\
\hline \multirow{2}{*}{ Growth opportunities } & $-0.01^{\mathrm{a}}$ & $-0.009^{\mathrm{a}}$ & $-0.004^{\mathrm{a}}$ & $-0.01^{\mathrm{a}}$ & $-0.009^{\mathrm{a}}$ & -0.003 \\
\hline & -19.86 & -17.96 & -2.22 & -19.85 & -17.99 & -1.39 \\
\hline \multirow[t]{2}{*}{ Size } & $0.01^{\mathrm{a}}$ & $0.007^{\mathrm{a}}$ & $0.032^{\mathrm{a}}$ & $0.01^{\mathrm{a}}$ & $0.007^{\mathrm{a}}$ & $0.032^{\mathrm{a}}$ \\
\hline & 19.85 & 12.38 & 20.84 & 19.96 & 12.41 & 21.09 \\
\hline \multirow[t]{2}{*}{ Tangibility } & $0.183^{\mathrm{a}}$ & $0.191^{\mathrm{a}}$ & $0.104^{\mathrm{a}}$ & $0.183^{\mathrm{a}}$ & $0.191^{\mathrm{a}}$ & $0.103^{\mathrm{a}}$ \\
\hline & 40.08 & 37.49 & 9.76 & 40.06 & 37.47 & 9.7 \\
\hline \multirow[t]{2}{*}{ Profitability } & $-0.068^{\mathrm{a}}$ & $-0.053^{\mathrm{a}}$ & $-0.538^{\mathrm{a}}$ & $-0.068^{\mathrm{a}}$ & $-0.053^{\mathrm{a}}$ & $-0.536^{\mathrm{a}}$ \\
\hline & -14.86 & -11.41 & -20.5 & -14.85 & -11.44 & -20.36 \\
\hline \multirow[t]{2}{*}{ Bond rate } & $0.067^{\mathrm{a}}$ & $0.075^{\mathrm{a}}$ & 0.008 & $0.067^{\mathrm{a}}$ & $0.075^{\mathrm{a}}$ & 0.019 \\
\hline & 23.21 & 25.27 & 0.67 & 23.17 & 25.24 & 1.63 \\
\hline \multirow[t]{2}{*}{ ADR } & 0.004 & 0.005 & 0.006 & 0.004 & 0.005 & 0.009 \\
\hline & 1.06 & 1.36 & 0.76 & 1.09 & 1.35 & 0.73 \\
\hline \multirow[t]{2}{*}{ Inflation } & $-0.024^{\mathrm{b}}$ & $-0.326^{\mathrm{b}}$ & $-0.032^{\mathrm{a}}$ & -0.017 & $-0.245^{\mathrm{c}}$ & 0.006 \\
\hline & -2.31 & -2.34 & -2.71 & -1.62 & -1.65 & 0.75 \\
\hline \multirow[t]{2}{*}{ High inflation } & 0.002 & 0.001 & -0.001 & 0.001 & 0 & 0.004 \\
\hline & 0.72 & 0.24 & -0.15 & 0.28 & -0.11 & 0.37 \\
\hline \multirow[t]{2}{*}{ GDP per capita } & $0.205^{\mathrm{a}}$ & $0.317^{\mathrm{a}}$ & $0.13^{\mathrm{a}}$ & $0.151^{\mathrm{a}}$ & $0.296^{\mathrm{a}}$ & 0.056 \\
\hline & 6.31 & 6.07 & 2.67 & 4.31 & 4.87 & 1.04 \\
\hline \multirow[t]{2}{*}{ GDP growth } & -0.061 & $-0.132^{\mathrm{b}}$ & -0.079 & -0.049 & $-0.125^{b}$ & -0.119 \\
\hline & -1.47 & -2.53 & -0.84 & -1.19 & -2.38 & -1.23 \\
\hline \multirow[t]{2}{*}{ Growth volatility } & $-0.453^{\mathrm{a}}$ & $-0.341^{\mathrm{a}}$ & $-0.27^{\mathrm{c}}$ & $-0.445^{\mathrm{a}}$ & $-0.325^{\mathrm{a}}$ & $-0.382^{b}$ \\
\hline & -6.04 & -3.77 & -1.67 & -5.71 & -3.54 & -2.15 \\
\hline \multirow[t]{2}{*}{ Banking crisis } & -0.012 & & $-0.032^{\mathrm{a}}$ & 0.001 & 0 & $-0.03^{\mathrm{a}}$ \\
\hline & -1.18 & & -2.23 & 0.07 & . & -2.06 \\
\hline \multirow[t]{2}{*}{ Share turnover } & $-0.001^{\mathrm{a}}$ & $-0.001^{\mathrm{a}}$ & $-0.001^{\mathrm{a}}$ & $-0.001^{\mathrm{b}}$ & $-0.001^{b}$ & $-0.001^{\mathrm{c}}$ \\
\hline & -2.79 & -2.95 & -2.66 & -2.16 & -2.19 & -1.7 \\
\hline \multirow[t]{2}{*}{ Financial openness } & $0.016^{\mathrm{b}}$ & $0.007^{\mathrm{b}}$ & $0.146^{\mathrm{a}}$ & $0.015^{\mathrm{b}}$ & $0.006^{\mathrm{c}}$ & $0.131^{\mathrm{a}}$ \\
\hline & 2.55 & 2.34 & 3.45 & 2.45 & 1.83 & 3.06 \\
\hline \multirow[t]{2}{*}{ Financial liberalization } & $-0.096^{\mathrm{a}}$ & $0.115^{c}$ & $-0.059^{\mathrm{a}}$ & & & \\
\hline & -2.77 & 1.94 & -2.66 & & & \\
\hline
\end{tabular}


Table 2 - continued

\begin{tabular}{|c|c|c|c|c|c|c|}
\hline \multirow[b]{3}{*}{ Bank entry } & \multicolumn{3}{|c|}{ (1) } & \multicolumn{3}{|c|}{ (2) } \\
\hline & All sample & Advanced & Emerging & All sample & Advanced & Emerging \\
\hline & & & & -0.003 & $0.012^{\mathrm{b}}$ & $-0.073^{\mathrm{a}}$ \\
\hline & & & & -0.31 & 2.38 & -2.75 \\
\hline \multirow[t]{2}{*}{ Credit controls } & & & & -0.049 & $0.102^{\mathrm{a}}$ & -0.012 \\
\hline & & & & -1.55 & 2.65 & -0.74 \\
\hline \multirow[t]{2}{*}{ Interest rates } & & & & -0.027 & $-0.071^{\mathrm{c}}$ & $-0.047^{\mathrm{b}}$ \\
\hline & & & & -1.16 & -1.85 & -2.15 \\
\hline \multirow[t]{2}{*}{ Securities markets } & & & & $-0.103^{\mathrm{a}}$ & & $-0.031^{b}$ \\
\hline & & & & -4.18 & & -2.16 \\
\hline \multirow[t]{2}{*}{ Bank supervision } & & & & $-0.007^{b}$ & $-0.009^{c}$ & $-0.025^{c}$ \\
\hline & & & & -2.55 & -1.65 & -1.84 \\
\hline \multirow[t]{2}{*}{ Privatization } & & & & $0.055^{\mathrm{a}}$ & $0.053^{\mathrm{a}}$ & $0.04^{\mathrm{b}}$ \\
\hline & & & & 4.14 & 2.91 & 2 \\
\hline Adjusted R-square & 0.166 & 0.157 & 0.272 & 0.167 & 0.157 & 0.275 \\
\hline
\end{tabular}




\section{Table 3}

\section{Debt Maturity, Financial Openness and Financial Liberalization}

This table shows (1) how financial liberalization and financial openness affect debt maturity, controlling for the macroeconomic and firm level factors; and (2) how the six dimensions of financial liberalization (bank entry, credit control, interest rates, securities markets, bank supervision and privatization) affect debt maturity, controlling for financial openness, firm level factors and macroeconomic factors. The sample covers the period 1994-2002 for 22 advanced and 16 emerging countries. Variable definitions are given in Table 1. All independent variables are lagged by one period. Industry, country and year dummies are controlled. Standard errors are clustered by country. The labels $^{\text {a,b, c }}$ denote significance at the $1 \%, 5 \%$, and $10 \%$ level, respectively and t-statistics are given in italics.

\begin{tabular}{|c|c|c|c|c|c|c|}
\hline \multirow{4}{*}{ Intercept } & \multicolumn{3}{|c|}{ (1) } & \multicolumn{3}{|c|}{ (2) } \\
\hline & All sample & Advanced & Emerging & All sample & Advanced & Emerging \\
\hline & $1.078^{\mathrm{b}}$ & -1.202 & $1.691^{\mathrm{b}}$ & 0.698 & $-2.047^{c}$ & 1.114 \\
\hline & 2.32 & -1.28 & 2.42 & 1.39 & -1.82 & 1.45 \\
\hline \multirow[t]{2}{*}{ Growth opportunities } & $0.005^{\mathrm{a}}$ & $0.004^{\mathrm{a}}$ & 0.005 & $0.005^{\mathrm{a}}$ & $0.004^{\mathrm{a}}$ & 0.005 \\
\hline & 5.43 & 4.49 & 1.64 & 5.45 & 4.5 & 1.43 \\
\hline \multirow[t]{2}{*}{ Leverage } & $0.224^{\mathrm{a}}$ & $0.217^{\mathrm{a}}$ & $0.253^{\mathrm{a}}$ & $0.225^{\mathrm{a}}$ & $0.217^{\mathrm{a}}$ & $0.256^{\mathrm{a}}$ \\
\hline & 32.51 & 28.55 & 14.63 & 32.6 & 28.53 & 14.8 \\
\hline \multirow[t]{2}{*}{ Size } & $0.035^{\mathrm{a}}$ & $0.033^{\mathrm{a}}$ & $0.047^{\mathrm{a}}$ & $0.035^{\mathrm{a}}$ & $0.033^{\mathrm{a}}$ & $0.047^{\mathrm{a}}$ \\
\hline & 42.02 & 36.85 & 19.57 & 42.01 & 36.92 & 19.51 \\
\hline \multirow[t]{2}{*}{ Asset maturity } & $0.001^{\mathrm{a}}$ & $0.001^{\mathrm{a}}$ & 0.000 & $0.001^{\mathrm{a}}$ & $0.001^{\mathrm{a}}$ & 0.000 \\
\hline & 4.05 & 4.1 & 0.62 & 4.14 & 4.09 & 0.71 \\
\hline \multirow[t]{2}{*}{ Tangibility } & $0.222^{\mathrm{a}}$ & $0.209^{\mathrm{a}}$ & $0.293^{\mathrm{a}}$ & $0.222^{\mathrm{a}}$ & $0.209^{\mathrm{a}}$ & 0.292 \\
\hline & 28.61 & 23.99 & 16.24 & 28.54 & 23.97 & $16.17^{a}$ \\
\hline \multirow[t]{2}{*}{ Profitability } & $0.092^{\mathrm{a}}$ & $0.089^{\mathrm{a}}$ & $0.213^{\mathrm{a}}$ & $0.092^{\mathrm{a}}$ & $0.089^{\mathrm{a}}$ & $0.213^{\mathrm{a}}$ \\
\hline & 13.92 & 13.07 & 5.75 & 13.87 & 12.99 & 5.74 \\
\hline \multirow[t]{2}{*}{ Volatility } & $-0.076^{\mathrm{a}}$ & $-0.085^{\mathrm{a}}$ & -0.016 & $-0.075^{\mathrm{a}}$ & $0.037^{\mathrm{a}}$ & $0.043^{\mathrm{b}}$ \\
\hline & -15.09 & -15.49 & -1.23 & -14.92 & 9.19 & 1.98 \\
\hline \multirow[t]{2}{*}{ Bond rate } & $0.032^{\mathrm{a}}$ & $0.037^{\mathrm{a}}$ & $0.044^{\mathrm{b}}$ & $0.032^{\mathrm{a}}$ & $0.031^{\mathrm{a}}$ & -0.006 \\
\hline & 8.17 & 9.18 & 2.02 & 8.18 & 4.96 & -0.49 \\
\hline \multirow[t]{2}{*}{ ADR } & $0.024^{\mathrm{a}}$ & $0.031^{\mathrm{a}}$ & 0.005 & $0.024^{\mathrm{a}}$ & $-0.085^{\mathrm{a}}$ & -0.017 \\
\hline & 4.3 & 4.95 & 0.42 & 4.32 & -15.4 & -1.37 \\
\hline \multirow[t]{2}{*}{ Inflation } & 0.011 & $-0.550^{b}$ & 0.002 & 0.007 & -0.283 & -0.014 \\
\hline & 0.77 & -2.31 & 0.15 & 0.51 & -1.11 & -0.88 \\
\hline \multirow[t]{2}{*}{ High inflation } & $-0.008^{\mathrm{c}}$ & 0.002 & -0.020 & -0.006 & -0.003 & $-0.028^{c}$ \\
\hline & -1.78 & 0.26 & -1.42 & -1.38 & -0.47 & -1.78 \\
\hline \multirow[t]{2}{*}{ GDP per capita } & $-0.142^{\mathrm{a}}$ & 0.113 & $-0.207^{\mathrm{a}}$ & $-0.101^{\mathrm{c}}$ & $0.189^{c}$ & $-0.151^{\mathrm{c}}$ \\
\hline & -2.87 & 1.27 & -2.84 & -1.85 & 1.76 & -1.84 \\
\hline \multirow[t]{2}{*}{ GDP growth } & 0.017 & $-0.212^{b}$ & 0.046 & 0.001 & $-0.214^{b}$ & 0.060 \\
\hline & 0.25 & -2.15 & 0.31 & 0.02 & -2.16 & 0.4 \\
\hline \multirow[t]{2}{*}{ Growth volatility } & -0.019 & $-0.319^{b}$ & -0.058 & 0.005 & -0.252 & 0.179 \\
\hline & -0.16 & -1.99 & -0.24 & 0.04 & -1.55 & 0.64 \\
\hline \multirow[t]{2}{*}{ Banking crisis } & -0.018 & 0.000 & -0.011 & -0.022 & & -0.018 \\
\hline & -1.24 & . & -0.51 & -1.49 & & -0.8 \\
\hline \multirow[t]{2}{*}{ Share turnover } & $-0.001^{b}$ & $-0.001^{\mathrm{a}}$ & -0.001 & -0.001 & -0.001 & -0.001 \\
\hline & -2.31 & -3.15 & -0.64 & -1.25 & -1.55 & -1.18 \\
\hline
\end{tabular}


Table 3 - continued

\begin{tabular}{lcccccc}
\hline & & $(1)$ & & \multicolumn{2}{c}{$(2)$} \\
& All sample & Advanced & Emerging & All sample & Advanced & Emerging \\
Financial openness & $0.062^{\mathrm{a}}$ & $0.059^{\mathrm{a}}$ & $-0.206^{\mathrm{a}}$ & $0.058^{\mathrm{a}}$ & $0.049^{\mathrm{a}}$ & $-0.165^{\mathrm{b}}$ \\
& 5.96 & 4.88 & -3.1 & 5.54 & 3.85 & -2.42 \\
Financial liberalization & $0.121^{\mathrm{b}}$ & $0.240^{\mathrm{b}}$ & -0.024 & & & \\
& 2.13 & 2.42 & -0.29 & & & \\
Bank entry & & & & -0.020 & 0.014 & -0.047 \\
& & & -1.41 & 1.47 & -1.28 \\
Credit controls & & & 0.057 & 0.050 & -0.005 \\
& & & 1.47 & 0.69 & -0.19 \\
Interest rates & & & 0.022 & $0.107^{\mathrm{c}}$ & 0.005 \\
& & & & 0.62 & 1.94 & 0.1 \\
Securities markets & & & $0.075^{\mathrm{c}}$ & & $0.132^{\mathrm{a}}$ \\
Supervision & & & 1.83 & & 2.85 \\
& & & -0.004 & $0.063^{\mathrm{a}}$ & -0.021 \\
Privatization & & & -0.23 & 2.72 & -0.73 \\
& & & & $-0.002^{\mathrm{c}}$ & $0.138^{\mathrm{a}}$ & $-0.081^{\mathrm{b}}$ \\
R-square & & & -1.85 & 4.28 & -2.65 \\
\hline
\end{tabular}


Table 4

The Impact of Financial Openness and Financial Liberalization on Leverage and Debt Maturity for Constrained and Unconstrained Firms

This table shows the effects of financial liberalization and financial openness on leverage and debt maturity for constrained and unconstrained firms, controlling for the macroeconomic and firm level factors. A firm in a given country in a given year is considered as constrained if the firm is not paying dividend and the Tobin's Q of the firm is above one or above the median Tobin's Q of that country. There are 15,808 observations in the constrained sample (14,120 from advanced market countries and 1688 from emerging market countries). Unconstrained sample has 55,607 observations (47,277 from advanced market countries and 8,330 from emerging market countries). The results are reported for advanced and emerging market countries. Variable definitions are given in Table 1. Industry, country and year dummies are controlled. Standard errors are clustered by country. All independent variables are lagged by one period. The labels ${ }^{\text {a, }}$ b, c denote significance at the 1\%, 5\%, and 10\% level, respectively and t-statistics are given in italics.

Panel A: Leverage

\begin{tabular}{|c|c|c|c|c|c|c|c|c|}
\hline \multirow{4}{*}{ Intercept } & \multicolumn{4}{|c|}{ Advanced } & \multicolumn{4}{|c|}{ Emerging } \\
\hline & \multicolumn{2}{|c|}{ Constrained } & \multicolumn{2}{|c|}{ Unconstrained } & \multicolumn{2}{|c|}{ Constrained } & \multicolumn{2}{|c|}{ Unconstrained } \\
\hline & -1.465 & $-3.465^{c}$ & $-2.944^{\mathrm{a}}$ & $-2.715^{\mathrm{a}}$ & -0.806 & -0.964 & $-1.780^{\mathrm{a}}$ & -0.377 \\
\hline & -0.87 & -1.69 & -5.23 & -4.11 & -0.59 & -0.65 & -3.71 & -0.72 \\
\hline \multirow[t]{2}{*}{ Growth opportunities } & $-0.009^{\mathrm{a}}$ & $-0.009^{\mathrm{a}}$ & $-0.011^{\mathrm{a}}$ & $-0.011^{\mathrm{a}}$ & $-0.018^{\mathrm{a}}$ & $-0.016^{\mathrm{a}}$ & $-0.012^{\mathrm{a}}$ & $-0.011^{\mathrm{a}}$ \\
\hline & -12.17 & -12.08 & -13.91 & -13.94 & -3.94 & -3.53 & -6.58 & -5.75 \\
\hline \multirow[t]{2}{*}{ Size } & $0.002^{\mathrm{c}}$ & $0.003^{\mathrm{c}}$ & $0.010^{\mathrm{a}}$ & $0.010^{\mathrm{a}}$ & $0.032^{\mathrm{a}}$ & $0.033^{\mathrm{a}}$ & $0.033^{\mathrm{a}}$ & $0.033^{\mathrm{a}}$ \\
\hline & 1.87 & 1.92 & 16.62 & 16.62 & 7.56 & 7.67 & 21.20 & 21.44 \\
\hline \multirow[t]{2}{*}{ Tangibility } & $0.210^{\mathrm{a}}$ & $0.210^{\mathrm{a}}$ & $0.177^{\mathrm{a}}$ & $0.177^{\mathrm{a}}$ & $0.086^{\mathrm{a}}$ & $0.082^{\mathrm{a}}$ & $0.099^{\mathrm{a}}$ & $0.098^{\mathrm{a}}$ \\
\hline & 18.01 & 17.98 & 32.67 & 32.66 & 3.08 & 2.93 & 9.30 & 9.20 \\
\hline \multirow[t]{2}{*}{ Profitability } & $-0.068^{\mathrm{a}}$ & $-0.068^{\mathrm{a}}$ & $-0.021^{\mathrm{a}}$ & $-0.021^{\mathrm{a}}$ & $-0.328^{\mathrm{a}}$ & $-0.324^{\mathrm{a}}$ & $-0.411^{\mathrm{a}}$ & $-0.411^{\mathrm{a}}$ \\
\hline & -10.19 & -10.22 & -3.25 & -3.27 & -6.18 & -6.08 & -15.89 & -15.76 \\
\hline \multirow[t]{2}{*}{ Bond rate } & $0.128^{\mathrm{a}}$ & $0.129^{\mathrm{a}}$ & $0.059^{\mathrm{a}}$ & $0.059^{\mathrm{a}}$ & 0.028 & 0.029 & 0.002 & 0.003 \\
\hline & 16.43 & 16.45 & 18.97 & 18.95 & 0.85 & 0.88 & 0.19 & 0.26 \\
\hline \multirow[t]{2}{*}{ ADR } & 0.001 & 0.000 & 0.005 & 0.005 & 0.032 & 0.038 & $0.014^{\mathrm{c}}$ & $0.014^{\mathrm{c}}$ \\
\hline & 0.08 & 0.04 & 1.16 & 1.15 & 1.45 & 1.06 & 1.74 & 1.76 \\
\hline \multirow[t]{2}{*}{ Inflation } & -0.393 & -0.173 & -0.185 & -0.136 & -0.038 & -0.022 & $-0.021^{\mathrm{b}}$ & -0.006 \\
\hline & -1.01 & -0.42 & -1.27 & -0.88 & -1.02 & -0.58 & -1.96 & -0.55 \\
\hline \multirow[t]{2}{*}{ High inflation } & 0.003 & -0.002 & -0.003 & -0.004 & 0.008 & 0.008 & -0.001 & 0.000 \\
\hline & 0.35 & -0.19 & -0.84 & -1.02 & 0.33 & 0.30 & -0.08 & -0.01 \\
\hline \multirow[t]{2}{*}{ GDP per capita } & 0.145 & $0.320^{c}$ & $0.294^{\mathrm{a}}$ & $0.264^{\mathrm{a}}$ & 0.078 & 0.133 & $0.151^{\mathrm{a}}$ & 0.009 \\
\hline & 0.91 & 1.66 & 5.49 & 4.21 & 0.54 & 0.84 & 3.02 & 0.16 \\
\hline \multirow[t]{2}{*}{ GDP growth } & -0.011 & -0.009 & -0.079 & -0.070 & 0.420 & 0.227 & $-0.162^{\mathrm{C}}$ & $-0.202^{\mathrm{b}}$ \\
\hline & -0.06 & -0.05 & -1.50 & -1.32 & 1.61 & 0.83 & -1.71 & -2.10 \\
\hline \multirow[t]{2}{*}{ Growth volatility } & -0.432 & -0.316 & $-0.329^{a}$ & $-0.321^{\mathrm{a}}$ & -0.189 & -0.216 & $-0.622^{\mathrm{a}}$ & $-0.724^{\mathrm{a}}$ \\
\hline & -1.11 & -0.79 & -3.67 & -3.53 & -0.38 & -0.37 & -3.98 & -4.19 \\
\hline \multirow[t]{2}{*}{ Banking crisis } & & & & & 0.059 & 0.032 & -0.049 & -0.046 \\
\hline & & & & & 1.50 & 0.80 & -3.45 & -3.18 \\
\hline
\end{tabular}


Table 4, Panel A - continued

\begin{tabular}{|c|c|c|c|c|c|c|c|c|}
\hline \multirow[b]{3}{*}{ Share turnover } & \multicolumn{4}{|c|}{ Advanced } & \multicolumn{4}{|c|}{ Emerging } \\
\hline & \multicolumn{2}{|c|}{ Constrained } & \multicolumn{2}{|c|}{ Unconstrained } & \multicolumn{2}{|c|}{ Constrained } & \multicolumn{2}{|c|}{ Unconstrained } \\
\hline & -0.001 & 0.001 & $-0.001^{\mathrm{a}}$ & $-0.001^{\mathrm{a}}$ & -0.001 & -0.001 & $-0.001^{\mathrm{a}}$ & $-0.001^{\mathrm{b}}$ \\
\hline & -0.55 & 0.55 & -3.59 & -3.08 & -0.23 & -0.43 & -2.88 & -2.14 \\
\hline \multirow[t]{2}{*}{ Financial openness } & $0.044^{\mathrm{c}}$ & $0.058^{\mathrm{c}}$ & $0.002^{\mathrm{c}}$ & $0.002^{c}$ & $0.041^{\mathrm{c}}$ & $0.001^{\mathrm{c}}$ & $0.158^{\mathrm{a}}$ & $0.139^{\mathrm{a}}$ \\
\hline & 1.85 & 1.76 & 1.72 & 1.76 & 1.69 & 1.75 & 3.52 & 3.10 \\
\hline \multirow[t]{2}{*}{ Financial liberalization } & $0.306^{\mathrm{c}}$ & & 0.014 & & -0.072 & & -0.043 & \\
\hline & 1.88 & & 1.20 & & -1.50 & & -1.50 & \\
\hline \multirow[t]{2}{*}{ Bank entry } & & 0.019 & & -0.001 & & $-0.250^{\mathrm{a}}$ & & $-0.086^{\mathrm{a}}$ \\
\hline & & 0.66 & & -0.06 & & -3.56 & & -3.16 \\
\hline \multirow[t]{2}{*}{ Credit controls } & & $0.215^{\mathrm{c}}$ & & $0.086^{\mathrm{b}}$ & & 0.001 & & -0.016 \\
\hline & & 1.69 & & 2.23 & & 1.05 & & -1.01 \\
\hline \multirow[t]{2}{*}{ Interest rates } & & -0.015 & & -0.060 & & $-0.172^{\mathrm{c}}$ & & -0.019 \\
\hline & & 0.20 & & -0.56 & & -1.69 & & -0.63 \\
\hline \multirow[t]{2}{*}{ Securities markets } & & & & & & 0.019 & & 0.008 \\
\hline & & & & & & 0.14 & & 0.29 \\
\hline \multirow[t]{2}{*}{ Supervision } & & $0.102^{b}$ & & $-0.009^{c}$ & & 0.008 & & $-0.020^{c}$ \\
\hline & & 2.23 & & -1.69 & & 1.20 & & -1.66 \\
\hline \multirow[t]{2}{*}{ Privatization } & & $0.098^{\mathrm{c}}$ & & 0.021 & & $-0.091^{\mathrm{c}}$ & & $0.069^{\mathrm{a}}$ \\
\hline & & 1.75 & & 1.12 & & -1.85 & & 3.39 \\
\hline R-square & 0.273 & 0.273 & 0.156 & 0.156 & 0.401 & 0.407 & 0.268 & 0.274 \\
\hline
\end{tabular}


Table 4 - continued

Panel B: Debt Maturity

\begin{tabular}{|c|c|c|c|c|c|c|c|c|}
\hline \multirow{4}{*}{ Intercept } & \multicolumn{4}{|c|}{ Advanced } & \multicolumn{4}{|c|}{ Emerging } \\
\hline & \multicolumn{2}{|c|}{ Constrained } & \multicolumn{2}{|c|}{ Unconstrained } & \multicolumn{2}{|c|}{ Constrained } & \multicolumn{2}{|c|}{ Unconstrained } \\
\hline & 1.945 & -0.286 & $-1.750^{c}$ & $-2.072^{\mathrm{c}}$ & $4.102^{\mathrm{b}}$ & 3.024 & -0.023 & -0.257 \\
\hline & 0.76 & -0.09 & -1.72 & -1.71 & 2.35 & 1.58 & -0.03 & -0.29 \\
\hline \multirow[t]{2}{*}{ Growth opportunities } & $0.003^{\mathrm{b}}$ & $0.003^{\mathrm{b}}$ & 0.001 & 0.001 & 0.011 & 0.010 & $0.008^{\mathrm{b}}$ & $0.007^{\mathrm{C}}$ \\
\hline & 2.27 & 2.32 & 0.59 & 0.57 & 1.50 & 1.30 & 1.98 & 1.83 \\
\hline \multirow[t]{2}{*}{ Leverage } & $0.190^{\mathrm{a}}$ & $0.190^{\mathrm{a}}$ & $0.244^{\mathrm{a}}$ & $0.244^{\mathrm{a}}$ & $0.245^{\mathrm{a}}$ & $0.246^{\mathrm{a}}$ & $0.274^{\mathrm{a}}$ & $0.276^{\mathrm{a}}$ \\
\hline & 12.83 & 12.81 & 26.69 & 26.69 & 6.28 & 6.36 & 13.59 & 13.67 \\
\hline \multirow[t]{2}{*}{ Size } & $0.045^{\mathrm{a}}$ & $0.045^{\mathrm{a}}$ & $0.031^{\mathrm{a}}$ & $0.031^{\mathrm{a}}$ & $0.050^{\mathrm{a}}$ & $0.050^{\mathrm{a}}$ & $0.044^{\mathrm{a}}$ & $0.044^{\mathrm{a}}$ \\
\hline & 22.17 & 22.19 & 30.76 & 30.79 & 7.91 & 7.98 & 16.68 & 16.61 \\
\hline \multirow[t]{2}{*}{ Asset maturity } & $0.001^{\mathrm{b}}$ & $0.001^{\mathrm{b}}$ & $0.001^{\mathrm{b}}$ & $0.001^{\mathrm{b}}$ & 0.001 & 0.001 & 0.001 & 0.001 \\
\hline & 2.11 & 2.07 & 2.43 & 2.44 & 0.21 & 0.07 & 0.56 & 0.61 \\
\hline \multirow[t]{2}{*}{ Tangibility } & $0.170^{\mathrm{a}}$ & $0.170^{\mathrm{a}}$ & $0.234^{\mathrm{a}}$ & $0.233^{\mathrm{a}}$ & $0.203^{\mathrm{a}}$ & $0.198^{\mathrm{a}}$ & $0.310^{\mathrm{a}}$ & $0.309^{\mathrm{a}}$ \\
\hline & 9.94 & 9.94 & 22.80 & 22.75 & 4.89 & 4.73 & 15.53 & 15.51 \\
\hline \multirow[t]{2}{*}{ Profitability } & $0.079^{\mathrm{a}}$ & $0.079^{\mathrm{a}}$ & $0.099^{\mathrm{a}}$ & $0.098^{\mathrm{a}}$ & $0.162^{\mathrm{b}}$ & $0.166^{\mathrm{b}}$ & $0.185^{\mathrm{a}}$ & $0.183^{\mathrm{a}}$ \\
\hline & 8.48 & 8.44 & 8.98 & 8.93 & 2.31 & 2.38 & 4.15 & 4.12 \\
\hline \multirow[t]{2}{*}{ Volatility } & $-0.075^{\mathrm{a}}$ & $-0.074^{\mathrm{a}}$ & $-0.089^{a}$ & $-0.088^{\mathrm{a}}$ & -0.013 & -0.017 & -0.020 & -0.022 \\
\hline & -7.63 & -7.60 & -13.17 & -13.10 & -0.47 & -0.63 & -1.39 & -1.52 \\
\hline \multirow[t]{2}{*}{ Bond rate } & $0.058^{\mathrm{a}}$ & $0.058^{\mathrm{a}}$ & $0.032^{\mathrm{a}}$ & $0.032^{\mathrm{a}}$ & -0.009 & -0.013 & $0.053^{\mathrm{b}}$ & $0.053^{\mathrm{b}}$ \\
\hline & 6.42 & 6.45 & 7.21 & 7.20 & -0.18 & -0.25 & 2.26 & 2.25 \\
\hline \multirow[t]{2}{*}{ ADR } & -0.012 & -0.013 & $0.029^{\mathrm{a}}$ & $0.029^{\mathrm{a}}$ & -0.036 & -0.040 & -0.001 & -0.001 \\
\hline & -0.55 & -0.58 & 4.45 & 4.45 & -1.09 & -1.25 & -0.08 & -0.10 \\
\hline \multirow[t]{2}{*}{ Inflation } & -0.320 & -0.072 & $-0.643^{\mathrm{a}}$ & -0.426 & 0.036 & 0.022 & -0.009 & -0.022 \\
\hline & -0.50 & -0.11 & -2.50 & -1.55 & 0.79 & 0.47 & -0.55 & -1.25 \\
\hline \multirow[t]{2}{*}{ High inflation } & -0.004 & -0.010 & 0.002 & -0.001 & $-0.161^{a}$ & $-0.155^{\mathrm{a}}$ & 0.008 & -0.002 \\
\hline & -0.27 & -0.62 & 0.28 & -0.22 & -5.05 & -4.26 & 0.49 & -0.11 \\
\hline \multirow[t]{2}{*}{ GDP per capita } & -0.198 & -0.005 & $0.164^{\mathrm{c}}$ & $0.193^{\mathrm{c}}$ & $-0.437^{\mathrm{b}}$ & -0.324 & -0.031 & -0.012 \\
\hline & -0.82 & -0.02 & 1.69 & 1.68 & -2.39 & -1.58 & -0.38 & -0.13 \\
\hline \multirow[t]{2}{*}{ GDP growth } & -0.485 & -0.482 & -0.162 & -0.161 & -0.051 & -0.215 & 0.054 & 0.088 \\
\hline & -1.62 & -1.62 & -1.55 & -1.54 & -0.15 & -0.58 & 0.33 & 0.53 \\
\hline \multirow[t]{2}{*}{ Growth volatility } & $-1.267^{\mathrm{b}}$ & $-1.139^{b}$ & -0.167 & -0.115 & -0.095 & -0.040 & 0.214 & 0.323 \\
\hline & -2.34 & -2.09 & -0.99 & -0.68 & -0.15 & -0.06 & 0.80 & 1.06 \\
\hline \multirow[t]{2}{*}{ Banking crisis } & & & & & 0.015 & -0.037 & -0.004 & -0.004 \\
\hline & & & & & 0.29 & -0.69 & -0.17 & -0.16 \\
\hline \multirow[t]{2}{*}{ Share turnover } & $-0.001^{\mathrm{a}}$ & $-0.001^{\mathrm{c}}$ & $-0.001^{\mathrm{c}}$ & -0.001 & -0.001 & -0.001 & -0.001 & -0.001 \\
\hline & -2.89 & -1.82 & -1.94 & -0.89 & -0.94 & -1.44 & -0.68 & -0.87 \\
\hline \multirow[t]{2}{*}{ Financial openness } & 0.033 & 0.018 & $0.064^{\mathrm{a}}$ & $0.058^{\mathrm{a}}$ & $-0.262^{\mathrm{c}}$ & -0.088 & $-0.181^{\mathrm{a}}$ & $-0.167^{\mathrm{a}}$ \\
\hline & 0.90 & 0.46 & 4.94 & 4.23 & -1.67 & -1.34 & -2.40 & -2.19 \\
\hline Financial liberalization & $0.392^{\mathrm{c}}$ & & $0.209^{c}$ & & -0.212 & & 0.057 & \\
\hline & 1.88 & & 1.91 & & -0.89 & & 0.65 & \\
\hline Bank entry & & 0.037 & & 0.140 & & $-0.173^{\mathrm{c}}$ & & 0.003 \\
\hline & & 0.84 & & 0.66 & & -1.70 & & 0.07 \\
\hline
\end{tabular}


Table 4, Panel B - continued

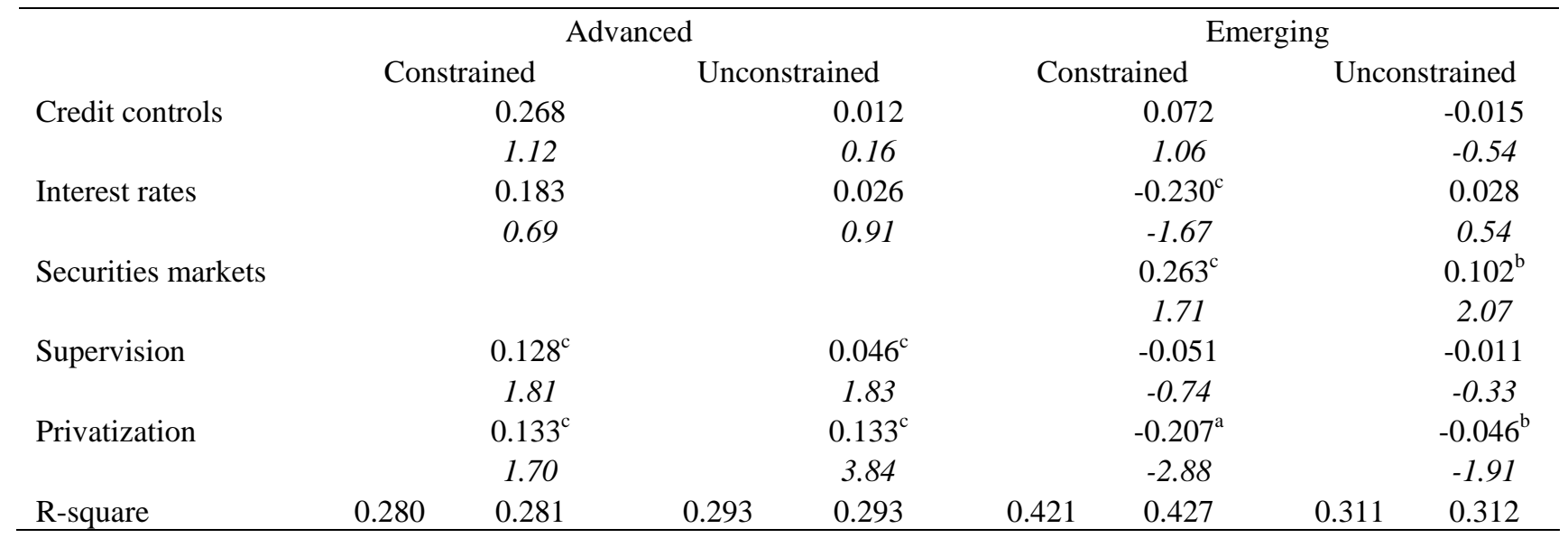




\section{Table 5}

Alternative Specifications with Financial Liberalization Index

This table shows how financial liberalization and financial openness affect leverage and debt maturity, controlling for the macroeconomic and firm level factors. There are three specifications reported: (1) Controlling with firm and year dummies; (2) With private control to GDP, creditor rights and ICRG composite index as additional variables; (3) With the interaction of bond rating and ADR dummies with financial liberalization index and financial openness. In specifications (2) and (3), industry, country and year dummies are controlled. Panel A shows results on leverage and Panel B shows results on debt maturity. ICRG composite is the ICRG composite country risk index; Private credit is private credit by deposit money banks to GDP; Creditor rights is the credit rights index of Djankov, McLiesh and Shleifer (2007). Other variables are as defined in Table 1. Standard errors are clustered by country. All independent variables are lagged by one period. The labels ${ }^{\text {a, b, c }}$ denote significance at the $1 \%, 5 \%$, and $10 \%$ level, respectively and t-statistics are given in italics.

Panel A: Leverage

\begin{tabular}{|c|c|c|c|c|c|c|c|c|c|}
\hline \multirow{4}{*}{ Intercept } & \multicolumn{3}{|c|}{ (1) } & \multicolumn{3}{|c|}{ (2) } & \multicolumn{3}{|c|}{ (3) } \\
\hline & All sample & Advanced & Emerging & All sample & Advanced & Emerging & All sample & Advanced & Emerging \\
\hline & -0.007 & 0.000 & 0.000 & $-1.683^{\mathrm{a}}$ & $-2.553^{\mathrm{a}}$ & 0.131 & $-1.747^{\mathrm{a}}$ & $-3.298^{\mathrm{a}}$ & $-1.610^{\mathrm{a}}$ \\
\hline & -0.86 & -0.35 & 0.06 & -4.83 & -3.83 & 0.21 & -5.70 & -5.99 & -3.43 \\
\hline \multirow[t]{2}{*}{ Growth opportunities } & $-0.004^{\mathrm{a}}$ & $-0.005^{\mathrm{a}}$ & -0.001 & $-0.010^{\mathrm{a}}$ & $-0.009^{a}$ & $-0.004^{\mathrm{b}}$ & $-0.010^{\mathrm{a}}$ & $-0.009^{\mathrm{a}}$ & $-0.004^{b}$ \\
\hline & -8.88 & -9.12 & -0.38 & -19.09 & -17.21 & -2.38 & -19.78 & -17.90 & -2.20 \\
\hline \multirow[t]{2}{*}{ Size } & $0.036^{\mathrm{a}}$ & $0.035^{\mathrm{a}}$ & $0.038^{\mathrm{a}}$ & $0.006^{\mathrm{a}}$ & $0.003^{\mathrm{a}}$ & $0.029^{\mathrm{a}}$ & $0.010^{\mathrm{a}}$ & $0.007^{\mathrm{a}}$ & $0.032^{\mathrm{a}}$ \\
\hline & 23.34 & 20.3 & 9.45 & 12.30 & 5.68 & 18.94 & 19.65 & 12.22 & 20.82 \\
\hline \multirow[t]{2}{*}{ Tangibility } & $0.128^{\mathrm{a}}$ & $0.125^{\mathrm{a}}$ & $0.118^{\mathrm{a}}$ & $0.177^{\mathrm{a}}$ & $0.184^{\mathrm{a}}$ & $0.104^{\mathrm{a}}$ & $0.184^{\mathrm{a}}$ & $0.191^{\mathrm{a}}$ & $0.104^{\mathrm{a}}$ \\
\hline & 16.1 & 13.71 & 7.38 & 38.60 & 36.15 & 9.70 & 40.09 & 37.50 & 9.78 \\
\hline \multirow[t]{2}{*}{ Profitability } & $-0.069^{\mathrm{a}}$ & $-0.060^{\mathrm{a}}$ & $-0.275^{\mathrm{a}}$ & $-0.096^{\mathrm{a}}$ & $-0.076^{\mathrm{a}}$ & $-0.603^{\mathrm{a}}$ & $-0.068^{\mathrm{a}}$ & $-0.053^{\mathrm{a}}$ & $-0.539^{\mathrm{a}}$ \\
\hline & -14.49 & -12.32 & -13.51 & -22.12 & -17.34 & -23.00 & -14.98 & -11.51 & -20.51 \\
\hline \multirow[t]{2}{*}{ Bond rate } & $0.021^{\mathrm{a}}$ & $0.020^{\mathrm{a}}$ & $0.040^{\mathrm{C}}$ & $0.068^{\mathrm{a}}$ & $0.076^{\mathrm{a}}$ & 0.008 & $0.091^{\mathrm{a}}$ & $0.059^{c}$ & $0.099^{\mathrm{b}}$ \\
\hline & 5.22 & 4.79 & 1.9 & 23.40 & 25.57 & 0.64 & 3.83 & 1.83 & 2.09 \\
\hline \multirow[t]{2}{*}{ ADR } & 0.007 & 0.000 & 0.003 & $0.011^{\mathrm{a}}$ & $0.013^{\mathrm{a}}$ & 0.007 & 0.031 & 0.005 & -0.031 \\
\hline & 0.77 & 0.04 & 0.18 & 3.10 & 3.22 & 0.89 & 1.34 & 0.10 & -1.00 \\
\hline \multirow[t]{2}{*}{ Inflation } & $-0.023^{\mathrm{a}}$ & 0.014 & $-0.028^{\mathrm{a}}$ & $-0.019^{c}$ & $-0.320^{\mathrm{b}}$ & $-0.024^{\mathrm{b}}$ & $-0.024^{\mathrm{b}}$ & $-0.335^{b}$ & $-0.031^{\mathrm{a}}$ \\
\hline & -3.35 & 0.21 & -3.79 & -1.88 & -2.04 & -1.97 & -2.38 & -2.40 & -2.68 \\
\hline \multirow[t]{2}{*}{ High inflation } & 0.004 & 0.000 & 0.003 & 0.004 & 0.000 & $-0.022^{b}$ & 0.002 & 0.001 & -0.001 \\
\hline & 1.27 & -0.11 & 0.63 & 1.31 & -0.05 & -2.05 & 0.62 & 0.25 & -0.13 \\
\hline \multirow[t]{2}{*}{ GDP per capita } & $0.057^{\mathrm{a}}$ & $0.208^{\mathrm{a}}$ & $0.164^{\mathrm{a}}$ & 0.221 & 0.263 & -0.023 & $0.209^{\mathrm{a}}$ & $0.325^{\mathrm{a}}$ & $0.135^{\mathrm{a}}$ \\
\hline & 4.86 & 7.37 & 4.94 & 5.94 & 4.11 & -0.35 & 6.43 & 6.21 & 2.77 \\
\hline \multirow[t]{2}{*}{ GDP growth } & $-0.037^{\mathrm{C}}$ & $-0.058^{\mathrm{b}}$ & $-0.116^{\mathrm{b}}$ & $-0.078^{\mathrm{C}}$ & -0.072 & -0.055 & -0.063 & $-0.138^{\mathrm{a}}$ & -0.081 \\
\hline & -1.82 & -2 & -2.41 & -1.80 & -1.29 & -0.55 & -1.52 & -2.64 & -0.86 \\
\hline
\end{tabular}


Table 5, Panel A - continued

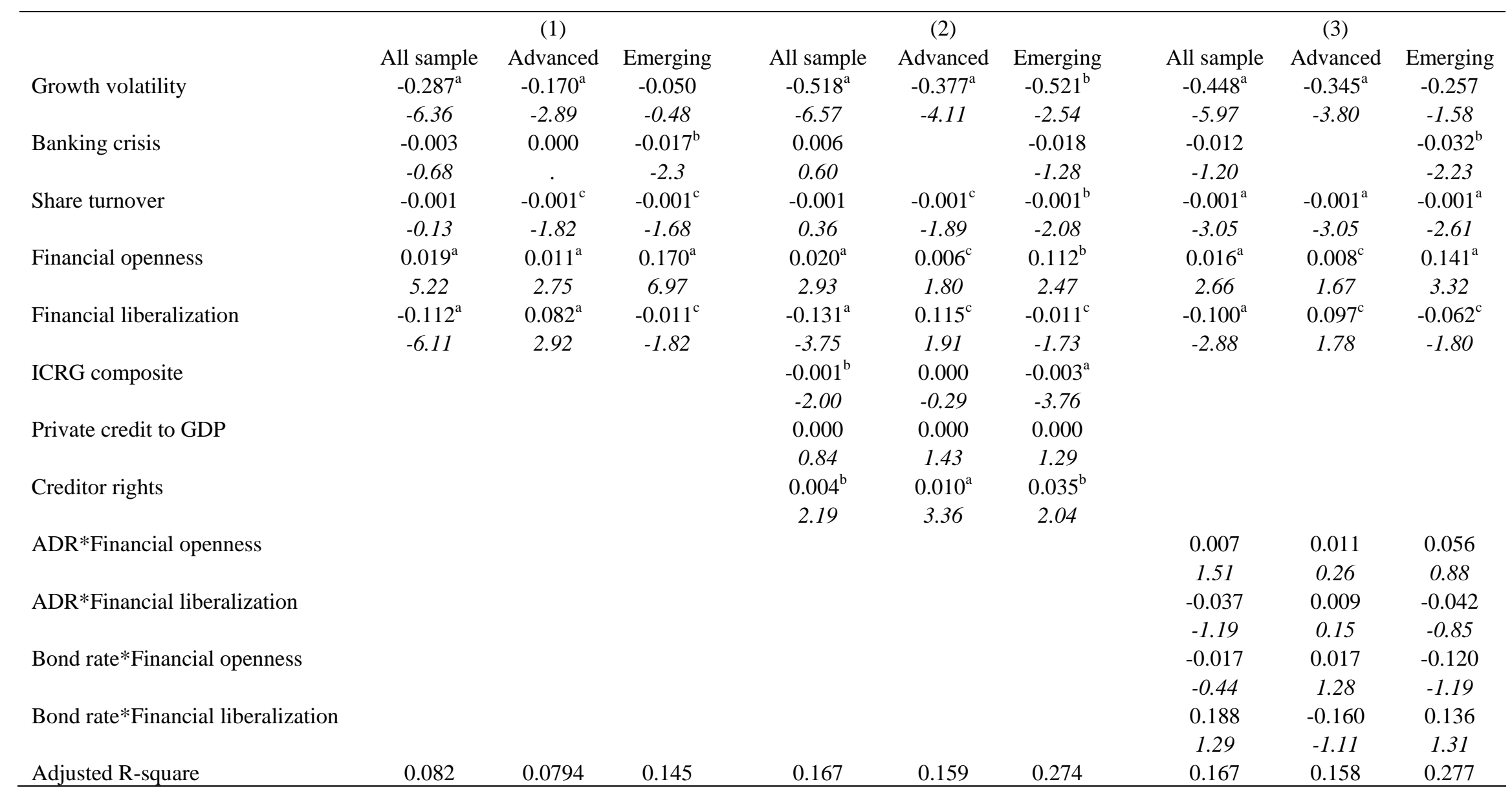


Table 5 - continued

Panel B: Debt Maturity

\begin{tabular}{|c|c|c|c|c|c|c|c|c|c|}
\hline & \multicolumn{3}{|c|}{ (1) } & \multicolumn{3}{|c|}{ (2) } & \multicolumn{3}{|c|}{ (3) } \\
\hline \multirow{3}{*}{ Intercept } & All Sample & Advanced & Emerging & All Sample & Advanced & Emerging & All Sample & Advanced & Emerging \\
\hline & 0.004 & 0.001 & 0.000 & $1.420^{\mathrm{a}}$ & 0.320 & 0.473 & $1.059^{\mathrm{b}}$ & -1.324 & $1.557^{\mathrm{b}}$ \\
\hline & 0.11 & 0.73 & -0.03 & 2.71 & 0.28 & 0.51 & 2.28 & -1.41 & 2.22 \\
\hline \multirow[t]{2}{*}{ Growth opportunities } & $0.005^{\mathrm{a}}$ & $0.005^{\mathrm{a}}$ & -0.002 & $0.005^{\mathrm{a}}$ & $0.004^{\mathrm{a}}$ & 0.004 & $0.005^{\mathrm{a}}$ & $0.004^{\mathrm{a}}$ & $0.005^{\mathrm{c}}$ \\
\hline & 4.96 & 5.2 & -0.54 & 5.49 & 4.54 & 1.35 & 5.44 & 4.51 & 1.66 \\
\hline \multirow[t]{2}{*}{ Leverage } & $0.139^{\mathrm{a}}$ & $0.143^{\mathrm{a}}$ & $0.146^{\mathrm{a}}$ & $0.224^{\mathrm{a}}$ & $0.217^{\mathrm{a}}$ & $0.253^{\mathrm{a}}$ & $0.224^{\mathrm{a}}$ & $0.216^{\mathrm{a}}$ & $0.252^{\mathrm{a}}$ \\
\hline & 12.76 & 11.76 & 5.71 & 32.5 & 28.54 & 14.65 & 32.42 & 28.43 & 14.57 \\
\hline \multirow[t]{2}{*}{ Size } & $0.029^{\mathrm{a}}$ & $0.030^{\mathrm{a}}$ & $0.016^{\mathrm{b}}$ & $0.035^{\mathrm{a}}$ & $0.033^{\mathrm{a}}$ & $0.047^{\mathrm{a}}$ & $0.035^{\mathrm{a}}$ & $0.033^{\mathrm{a}}$ & $0.047^{\mathrm{a}}$ \\
\hline & 9.85 & 9.02 & 2.19 & 42 & 36.79 & 19.37 & 41.9 & 36.64 & 19.55 \\
\hline \multirow[t]{2}{*}{ Asset maturity } & $0.001^{\mathrm{a}}$ & $0.001^{\mathrm{a}}$ & $0.001^{\mathrm{c}}$ & $0.001^{\mathrm{a}}$ & $0.001^{\mathrm{a}}$ & 0.001 & $0.001^{\mathrm{a}}$ & $0.001^{\mathrm{a}}$ & 0.001 \\
\hline & 5.37 & 5.04 & 1.66 & 4.04 & 4.09 & 0.52 & 4.02 & 4.08 & 0.59 \\
\hline \multirow[t]{2}{*}{ Tangibility } & $0.040^{\mathrm{a}}$ & 0.013 & $0.150^{\mathrm{a}}$ & $0.222^{\mathrm{a}}$ & $0.209^{\mathrm{a}}$ & $0.294^{\mathrm{a}}$ & $0.222^{\mathrm{a}}$ & $0.209^{\mathrm{a}}$ & $0.294^{\mathrm{a}}$ \\
\hline & 2.66 & 0.73 & 4.93 & 28.63 & 24.02 & 16.31 & 28.64 & 24.04 & 16.32 \\
\hline \multirow[t]{2}{*}{ Profitability } & $0.031^{\mathrm{a}}$ & $0.028^{\mathrm{a}}$ & $0.067^{\mathrm{b}}$ & $0.093^{\mathrm{a}}$ & $0.089^{\mathrm{a}}$ & $0.213^{\mathrm{a}}$ & $0.092^{\mathrm{a}}$ & $0.088^{\mathrm{a}}$ & $0.212^{\mathrm{a}}$ \\
\hline & 3.85 & 3.43 & 1.91 & 13.94 & 13.07 & 5.73 & 13.86 & 12.96 & 5.71 \\
\hline \multirow[t]{2}{*}{ Volatility } & $-0.030^{\mathrm{a}}$ & $-0.031^{\mathrm{a}}$ & -0.016 & $-0.076^{\mathrm{a}}$ & $-0.086^{\mathrm{a}}$ & -0.017 & $-0.076^{\mathrm{a}}$ & $-0.085^{\mathrm{a}}$ & -0.015 \\
\hline & -5.73 & -5.28 & -1.43 & -15.09 & -15.56 & -1.37 & -14.98 & -15.36 & -1.19 \\
\hline \multirow[t]{2}{*}{ Bond rate } & $0.031^{\mathrm{a}}$ & $0.032^{\mathrm{a}}$ & $0.001^{\mathrm{c}}$ & $0.031^{\mathrm{a}}$ & $0.036^{\mathrm{a}}$ & $0.045^{\mathrm{b}}$ & $-0.032^{\mathrm{a}}$ & $0.124^{\mathrm{a}}$ & 0.115 \\
\hline & 4.29 & 4.39 & 1.68 & 8.14 & 9.15 & 2.05 & 2.93 & 2.95 & 1.45 \\
\hline \multirow[t]{2}{*}{ ADR } & 0.023 & 0.002 & $0.061^{\mathrm{c}}$ & $0.024^{\mathrm{a}}$ & $0.031^{\mathrm{a}}$ & -0.005 & 0.051 & -0.038 & -0.073 \\
\hline & 1.21 & 0.07 & 1.79 & 4.31 & 4.94 & -0.42 & 1.36 & -0.5 & -1.42 \\
\hline \multirow[t]{2}{*}{ Inflation } & -0.001 & $-0.265^{c}$ & 0.002 & 0.011 & $-0.849^{a}$ & -0.004 & 0.010 & $-0.559^{b}$ & 0.004 \\
\hline & -0.08 & -1.8 & 0.17 & 0.81 & -3.19 & -0.26 & 0.76 & -2.34 & 0.24 \\
\hline \multirow[t]{2}{*}{ High inflation } & $-0.009^{\mathrm{a}}$ & -0.004 & -0.011 & $-0.008^{c}$ & 0.004 & -0.020 & $-0.008^{\mathrm{c}}$ & 0.002 & -0.019 \\
\hline & -2.72 & -0.95 & -0.97 & -1.87 & 0.7 & -1.29 & -1.84 & 0.26 & -1.39 \\
\hline \multirow[t]{2}{*}{ GDP per capita } & $-0.179^{a}$ & $0.141^{\mathrm{b}}$ & $-0.318^{\mathrm{a}}$ & $-0.176^{\mathrm{a}}$ & -0.031 & -0.055 & $-0.140^{\mathrm{a}}$ & 0.127 & $-0.193^{\mathrm{a}}$ \\
\hline & -7.31 & 2.24 & -4.94 & -3.14 & -0.28 & -0.57 & -2.83 & 1.41 & -2.64 \\
\hline \multirow[t]{2}{*}{ GDP growth } & 0.063 & $-0.127^{b}$ & 0.117 & 0.042 & -0.120 & -0.067 & 0.015 & $-0.221^{\mathrm{b}}$ & 0.035 \\
\hline & 1.45 & -1.99 & 1.07 & 0.58 & -1.13 & -0.43 & 0.21 & -2.24 & 0.24 \\
\hline \multirow[t]{2}{*}{ Growth volatility } & -0.167 & -0.006 & $-0.374^{\mathrm{C}}$ & -0.055 & $-0.337^{\mathrm{b}}$ & -0.406 & -0.025 & $-0.332^{\mathrm{b}}$ & -0.009 \\
\hline & 0.88 & -0.05 & -1.79 & -0.42 & -2.07 & -1.29 & -0.21 & -2.07 & -0.04 \\
\hline
\end{tabular}


Table 5, Panel B - continued

\begin{tabular}{|c|c|c|c|c|c|c|c|c|c|}
\hline \multirow{4}{*}{ Banking crisis } & \multicolumn{3}{|c|}{ (1) } & \multicolumn{3}{|c|}{ (2) } & \multicolumn{3}{|c|}{ (3) } \\
\hline & All Sample & Advanced & Emerging & All Sample & Advanced & Emerging & All Sample & Advanced & Emerging \\
\hline & $-0.029^{\mathrm{a}}$ & & -0.005 & -0.016 & & -0.003 & -0.018 & & -0.012 \\
\hline & -2.79 & & -0.33 & -1.07 & & -0.15 & -1.23 & & -0.55 \\
\hline \multirow[t]{2}{*}{ Share turnover } & $-0.001^{\mathrm{a}}$ & $-0.001^{\mathrm{a}}$ & $-0.001^{\mathrm{a}}$ & $-0.001^{b}$ & $-0.001^{\mathrm{a}}$ & -0.001 & $-0.001^{b}$ & $-0.001^{\mathrm{a}}$ & -0.001 \\
\hline & -4.38 & -4.48 & -2.36 & -2.34 & -3.38 & -0.52 & -2.42 & -3.24 & -0.56 \\
\hline \multirow[t]{2}{*}{ Financial openness } & $0.030^{\mathrm{a}}$ & $0.030^{\mathrm{a}}$ & $-0.139^{\mathrm{a}}$ & $0.058^{\mathrm{a}}$ & $0.049^{\mathrm{a}}$ & $-0.212^{\mathrm{a}}$ & $0.061^{\mathrm{a}}$ & $0.058^{\mathrm{a}}$ & $-0.224^{\mathrm{a}}$ \\
\hline & 3.81 & 3.32 & -2.67 & 5.07 & 3.72 & -2.95 & 5.81 & 4.73 & -3.36 \\
\hline \multirow[t]{2}{*}{ Financial liberalization } & $0.108^{\mathrm{a}}$ & $0.260^{\mathrm{a}}$ & -0.020 & $0.111^{\mathrm{b}}$ & $0.217^{\mathrm{b}}$ & -0.063 & $0.124^{\mathrm{b}}$ & $0.222^{\mathrm{b}}$ & -0.029 \\
\hline & 2.82 & 4.13 & -0.32 & 2.33 & 2.15 & -0.7 & 2.19 & 2.22 & -0.35 \\
\hline \multirow[t]{2}{*}{ ICRG composite } & & & & 0.000 & 0.000 & $-0.001^{\mathrm{b}}$ & & & \\
\hline & & & & -0.28 & 0.13 & -2.47 & & & \\
\hline \multirow[t]{2}{*}{ Private credit to GDP } & & & & 0.000 & 0.000 & 0.000 & & & \\
\hline & & & & -0.68 & 0.17 & -0.73 & & & \\
\hline \multirow[t]{2}{*}{ Creditor rights } & & & & $0.005^{\mathrm{b}}$ & $0.013^{\mathrm{a}}$ & -0.037 & & & \\
\hline & & & & 2.25 & 2.7 & -1.5 & & & \\
\hline \multirow[t]{2}{*}{ ADR*Financial openness } & & & & & & & -0.020 & -0.024 & -0.343 \\
\hline & & & & & & & -0.76 & -0.33 & -0.39 \\
\hline \multirow[t]{2}{*}{ ADR*Financial liberalization } & & & & & & & 0.114 & 0.020 & -0.009 \\
\hline & & & & & & & 1.22 & 0.21 & -0.12 \\
\hline \multirow[t]{2}{*}{ Bond rate*Financial openness } & & & & & & & $0.007^{\mathrm{b}}$ & $0.008^{\mathrm{C}}$ & 0.174 \\
\hline & & & & & & & 1.96 & 1.84 & 1.18 \\
\hline \multirow[t]{2}{*}{ Bond rate*Financial liberalization } & & & & & & & -0.077 & -0.186 & -0.205 \\
\hline & & & & & & & -0.92 & -1.02 & -1.48 \\
\hline Adjusted R-square & 0.043 & 0.044 & 0.049 & 0.298 & 0.284 & 0.316 & 0.296 & 0.283 & 0.316 \\
\hline
\end{tabular}




\section{Table 6}

\section{Alternative Specifications with the Components of Financial Liberalization Index}

This table shows how financial liberalization and financial openness affect leverage and debt maturity, controlling for the macroeconomic and firm level factors. There are two specifications reported: (1) Controlling with firm and year dummies; (2) With private control to GDP, creditor rights and ICRG composite index as additional variables and industry, country and year dummies are controlled. Panel A shows results on leverage and Panel B shows results on debt maturity. ICRG composite is the ICRG composite country risk index; Private credit is private credit by deposit money banks to GDP; Creditor rights is the credit rights index of Djankov, McLiesh and Shleifer (2007). Other variables are defined as defined in Table 1 . Standard errors are clustered by country. All independent variables are lagged by one period. The labels ${ }^{\mathrm{a}, \mathrm{b}, \mathrm{c}}$ denote significance at the $1 \%, 5 \%$, and $10 \%$ level, respectively and t-statistics are given in italics.

\section{Panel A: Leverage}

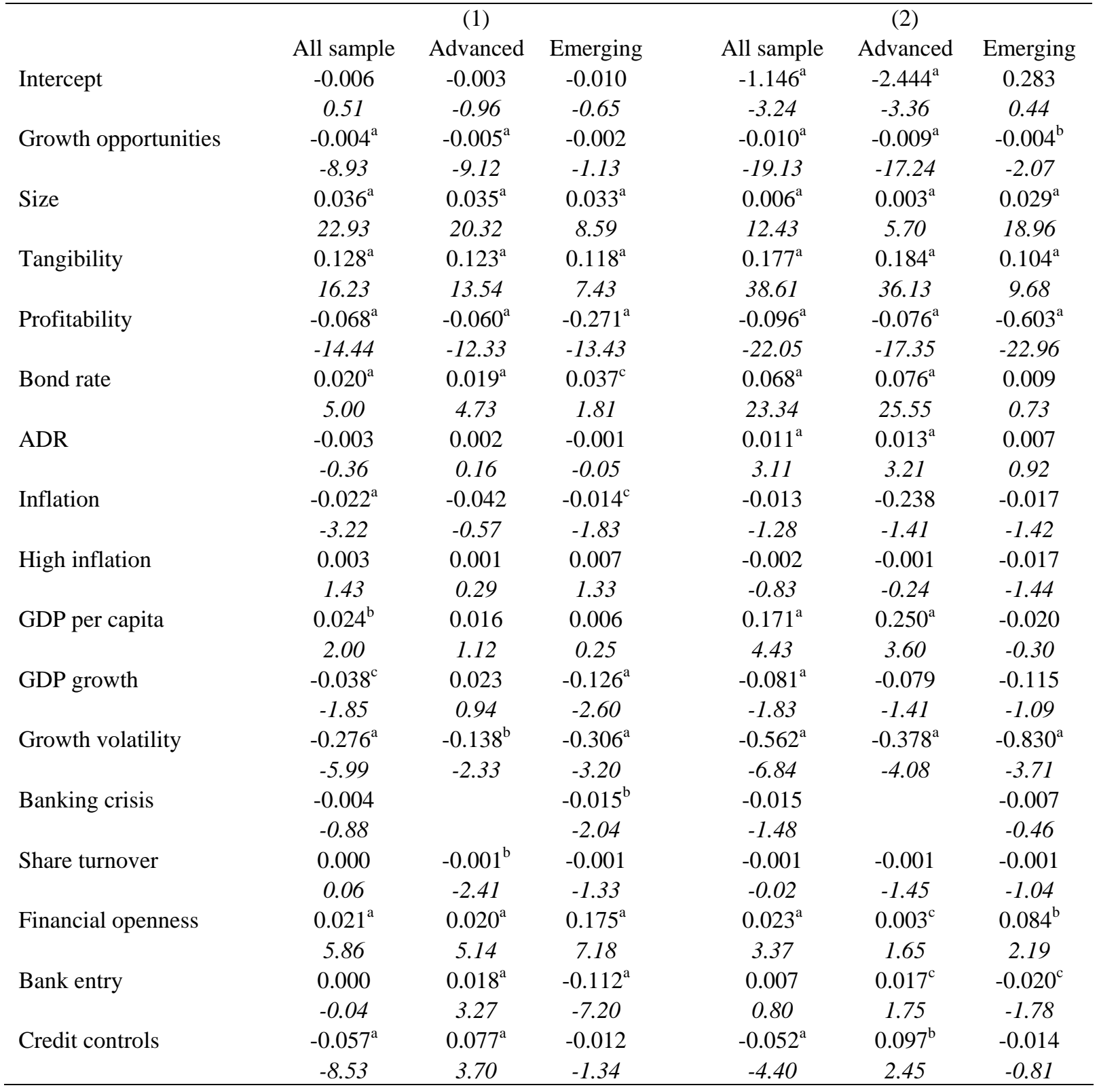


Table 6, Panel A - continued

\begin{tabular}{lcccccc}
\hline & & $(1)$ & & \multicolumn{2}{c}{$(2)$} \\
& All sample & Advanced & Emerging & All sample & Advanced & Emerging \\
Interest rates & -0.006 & $-0.071^{\mathrm{b}}$ & $-0.038^{\mathrm{b}}$ & 0.018 & $-0.062^{\mathrm{c}}$ & -0.022 \\
& -0.53 & -2.25 & -2.33 & 0.74 & -1.67 & -0.67 \\
Securities markets & $-0.022^{\mathrm{c}}$ & & $-0.025^{\mathrm{c}}$ & $-0.116^{\mathrm{a}}$ & & $-0.043^{\mathrm{c}}$ \\
& -1.66 & & -1.72 & -4.62 & & -1.68 \\
Supervision & $-0.025^{\mathrm{a}}$ & $-0.018^{\mathrm{a}}$ & $-0.030^{\mathrm{c}}$ & $-0.019^{\mathrm{c}}$ & 0.005 & $-0.028^{\mathrm{c}}$ \\
& -5.39 & -3.28 & -2.84 & -1.87 & 0.35 & -1.70 \\
Privatization & $0.026^{\mathrm{a}}$ & $0.005^{\mathrm{c}}$ & $0.032^{\mathrm{b}}$ & $0.048^{\mathrm{a}}$ & $0.039^{\mathrm{b}}$ & $0.051^{\mathrm{a}}$ \\
& 3.54 & 1.66 & 2.89 & 3.53 & 2.06 & 2.47 \\
ICRG composite & & & & $-0.001^{\mathrm{a}}$ & -0.001 & $-0.004^{\mathrm{a}}$ \\
& & & & -2.84 & -0.75 & -4.57 \\
Private credit to GDP & & & & 0.000 & 0.000 & 0.000 \\
& & & & 0.87 & 1.34 & 0.78 \\
Creditor rights & & & & 0.003 & $0.009^{\mathrm{a}}$ & 0.017 \\
& & & & 1.13 & 2.69 & 0.78 \\
Adjusted R-square & 0.085 & 0.079 & 0.153 & 0.168 & 0.158 & 0.278 \\
\hline
\end{tabular}


Table 6 - continued

Panel B: Debt Maturity

\begin{tabular}{|c|c|c|c|c|c|c|}
\hline \multirow{4}{*}{ Intercept } & \multicolumn{3}{|c|}{ (1) } & \multicolumn{3}{|c|}{ (2) } \\
\hline & All Sample & Advanced & Emerging & All Sample & Advanced & Emerging \\
\hline & 0.004 & 0.003 & 0.007 & $1.071^{\mathrm{b}}$ & -0.930 & -0.080 \\
\hline & 0.92 & 0.53 & 0.60 & 1.96 & -0.73 & -0.08 \\
\hline \multirow[t]{2}{*}{ Growth opportunities } & $0.005^{\mathrm{a}}$ & $0.005^{\mathrm{a}}$ & -0.005 & $0.005^{\mathrm{a}}$ & $0.004^{\mathrm{a}}$ & 0.004 \\
\hline & 4.94 & 5.24 & -1.27 & 5.52 & 4.56 & 1.34 \\
\hline \multirow[t]{2}{*}{ Leverage } & $0.141^{\mathrm{a}}$ & $0.145^{\mathrm{a}}$ & 0.156 & $0.225^{\mathrm{a}}$ & $0.217^{\mathrm{a}}$ & $0.256^{\mathrm{a}}$ \\
\hline & 12.91 & 11.92 & 6.10 & 32.60 & 28.53 & 14.79 \\
\hline \multirow[t]{2}{*}{ Size } & $0.029^{\mathrm{a}}$ & $0.031^{\mathrm{a}}$ & $0.022^{\mathrm{a}}$ & $0.035^{\mathrm{a}}$ & $0.033^{\mathrm{a}}$ & $0.047^{\mathrm{a}}$ \\
\hline & 9.90 & 9.39 & 3.00 & 41.99 & 36.85 & 19.38 \\
\hline \multirow[t]{2}{*}{ Asset maturity } & $0.001^{\mathrm{a}}$ & $0.001^{\mathrm{a}}$ & $0.001^{\mathrm{c}}$ & $0.001^{\mathrm{a}}$ & $0.001^{\mathrm{a}}$ & 0.001 \\
\hline & 5.52 & 4.98 & 1.81 & 4.13 & 4.07 & 0.60 \\
\hline \multirow[t]{2}{*}{ Tangibility } & $0.039^{\mathrm{a}}$ & 0.008 & $0.147^{\mathrm{a}}$ & $0.222^{\mathrm{a}}$ & $0.209^{\mathrm{a}}$ & $0.293^{\mathrm{a}}$ \\
\hline & 2.59 & 0.49 & 4.82 & 28.55 & 23.99 & 16.23 \\
\hline \multirow[t]{2}{*}{ Profitability } & $0.031^{\mathrm{a}}$ & $0.027^{\mathrm{a}}$ & $0.070^{\mathrm{b}}$ & $0.092^{\mathrm{a}}$ & $0.089^{\mathrm{a}}$ & $0.216^{\mathrm{a}}$ \\
\hline & 3.85 & 3.30 & 2.00 & 13.90 & 13.01 & 5.80 \\
\hline \multirow[t]{2}{*}{ Volatility } & $-0.030^{\mathrm{a}}$ & $-0.032^{\mathrm{a}}$ & $-0.022^{c}$ & $-0.075^{\mathrm{a}}$ & $-0.085^{\mathrm{a}}$ & -0.017 \\
\hline & -5.77 & -5.43 & -1.92 & -14.91 & -15.43 & -1.32 \\
\hline \multirow[t]{2}{*}{ Bond rate } & $0.032^{\mathrm{a}}$ & $0.033^{\mathrm{a}}$ & 0.007 & $0.032^{\mathrm{a}}$ & $0.036^{\mathrm{a}}$ & $0.044^{\mathrm{b}}$ \\
\hline & 4.36 & 4.43 & 0.17 & 8.16 & 9.17 & 2.01 \\
\hline \multirow[t]{2}{*}{ ADR } & 0.021 & -0.003 & $0.069^{\mathrm{b}}$ & $0.024^{\mathrm{a}}$ & $0.031^{\mathrm{a}}$ & -0.006 \\
\hline & 1.11 & -0.13 & 2.03 & 4.33 & 4.96 & -0.49 \\
\hline \multirow[t]{2}{*}{ Inflation } & -0.007 & 0.151 & -0.022 & 0.008 & $-0.539^{c}$ & -0.014 \\
\hline & -0.58 & 0.92 & -1.61 & 0.59 & -1.87 & -0.83 \\
\hline \multirow[t]{2}{*}{ High inflation } & $-0.008^{b}$ & -0.006 & $-0.028^{\mathrm{b}}$ & -0.007 & 0.000 & -0.018 \\
\hline & -2.47 & -1.60 & -2.33 & -1.49 & -0.04 & -1.01 \\
\hline \multirow[t]{2}{*}{ GDP per capita } & $-0.151^{\mathrm{a}}$ & $-0.196^{\mathrm{a}}$ & $-0.143^{\mathrm{a}}$ & $-0.139^{b}$ & 0.088 & -0.005 \\
\hline & -6.07 & -6.16 & -2.96 & -2.33 & 0.72 & -0.05 \\
\hline \multirow[t]{2}{*}{ GDP growth } & 0.056 & 0.048 & 0.087 & 0.033 & -0.141 & -0.100 \\
\hline & 1.28 & 0.88 & 0.83 & 0.45 & -1.32 & -0.61 \\
\hline \multirow[t]{2}{*}{ Growth volatility } & 0.202 & 0.108 & 0.101 & -0.016 & $-0.276^{\mathrm{c}}$ & -0.035 \\
\hline & 1.19 & 0.92 & 0.51 & -0.12 & -1.68 & -0.10 \\
\hline \multirow[t]{2}{*}{ Banking crisis } & $-0.035^{b}$ & & -0.018 & -0.019 & & -0.018 \\
\hline & -2.36 & & -1.13 & -1.27 & & -0.79 \\
\hline \multirow[t]{2}{*}{ Share turnover } & $-0.001^{\mathrm{a}}$ & $-0.001^{\mathrm{a}}$ & $-0.001^{\mathrm{a}}$ & -0.001 & -0.001 & -0.001 \\
\hline & -4.28 & -3.21 & -2.68 & -1.24 & -1.64 & -0.94 \\
\hline \multirow[t]{2}{*}{ Financial openness } & $0.030^{\mathrm{a}}$ & $0.036^{\mathrm{a}}$ & $-0.105^{b}$ & $0.052^{\mathrm{a}}$ & $0.042^{\mathrm{a}}$ & $-0.153^{b}$ \\
\hline & 3.83 & 4.15 & -2.00 & 4.54 & 3.02 & -2.05 \\
\hline \multirow[t]{2}{*}{ Bank entry } & 0.000 & 0.016 & -0.011 & -0.025 & 0.010 & $-0.103^{b}$ \\
\hline & -0.04 & 1.31 & -0.33 & -1.36 & 0.51 & -2.14 \\
\hline \multirow[t]{2}{*}{ Credit controls } & $0.028^{b}$ & 0.022 & -0.022 & $0.053^{\mathrm{a}}$ & 0.036 & -0.004 \\
\hline & 2.12 & 0.44 & -1.19 & 2.98 & 0.49 & -0.15 \\
\hline \multirow{2}{*}{ Interest rates } & 0.009 & $0.124^{\mathrm{C}}$ & 0.024 & 0.019 & 0.017 & -0.036 \\
\hline & 0.35 & 1.80 & 0.64 & 0.52 & 0.35 & -0.71 \\
\hline
\end{tabular}


Table 6, Panel B - continued

\begin{tabular}{|c|c|c|c|c|c|c|}
\hline \multirow{4}{*}{ Securities markets } & \multicolumn{3}{|c|}{ (1) } & \multicolumn{3}{|c|}{ (2) } \\
\hline & All Sample & Advanced & Emerging & All Sample & Advanced & Emerging \\
\hline & $0.130^{\mathrm{a}}$ & & $0.152^{\mathrm{a}}$ & $0.073^{\mathrm{c}}$ & & $0.115^{\mathrm{b}}$ \\
\hline & 4.53 & & 4.50 & 1.75 & & 2.43 \\
\hline \multirow[t]{2}{*}{ Supervision } & 0.004 & $0.018^{\mathrm{c}}$ & 0.003 & 0.001 & $0.065^{\mathrm{a}}$ & -0.022 \\
\hline & 0.39 & 1.71 & 0.12 & 0.09 & 2.80 & -0.75 \\
\hline \multirow[t]{2}{*}{ Privatization } & $-0.027^{\mathrm{c}}$ & $0.081^{\mathrm{a}}$ & $-0.107^{\mathrm{a}}$ & $-0.007^{\mathrm{c}}$ & $0.123^{\mathrm{a}}$ & $-0.078^{\mathrm{b}}$ \\
\hline & -1.72 & 3.50 & -4.66 & -1.82 & 3.69 & -2.45 \\
\hline \multirow[t]{2}{*}{ ICRG composite } & & & & -0.001 & -0.001 & $-0.001^{c}$ \\
\hline & & & & -1.41 & -0.25 & -1.66 \\
\hline \multirow[t]{2}{*}{ Private credit to GDP } & & & & 0.000 & 0.000 & 0.000 \\
\hline & & & & -0.83 & -0.05 & -0.60 \\
\hline \multirow[t]{2}{*}{ Creditor rights } & & & & $0.006^{\mathrm{c}}$ & $0.011^{\mathrm{a}}$ & -0.046 \\
\hline & & & & 1.67 & 2.24 & -1.53 \\
\hline Adjusted R-square & 0.043 & 0.044 & 0.052 & 0.296 & 0.284 & 0.317 \\
\hline
\end{tabular}


Figure 1: Evolution of Leverage, Debt Maturity, DFL index and financial openness

This figure shows time series of sample mean leverage, debt maturity, external private sector debt to GDP, and financial liberalization index in figures $1 \mathrm{~A}, 1 \mathrm{~B}, 1 \mathrm{C}$, and 1D, respectively. Each figure presents the values for overall sample, advanced countries and emerging countries.

Leverage

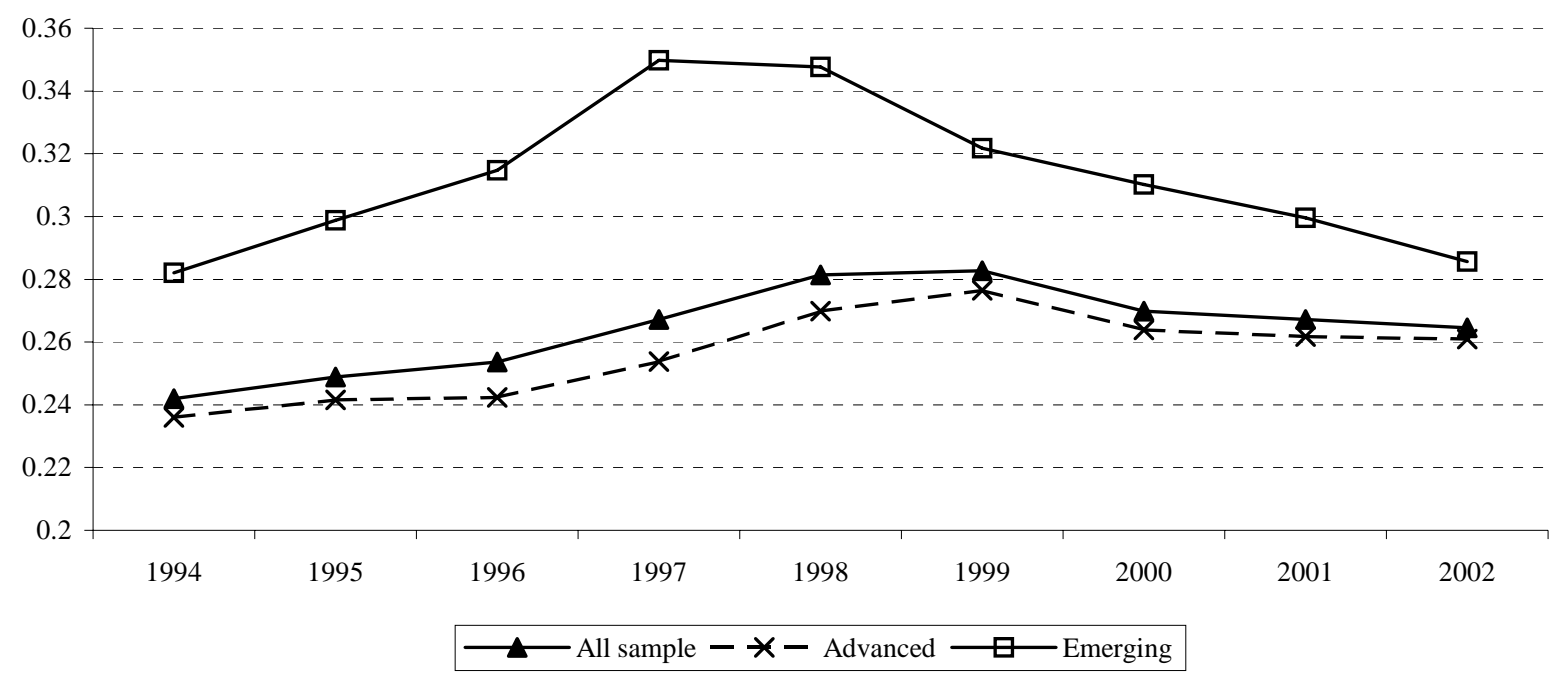

Figure 1A

Debt maturity

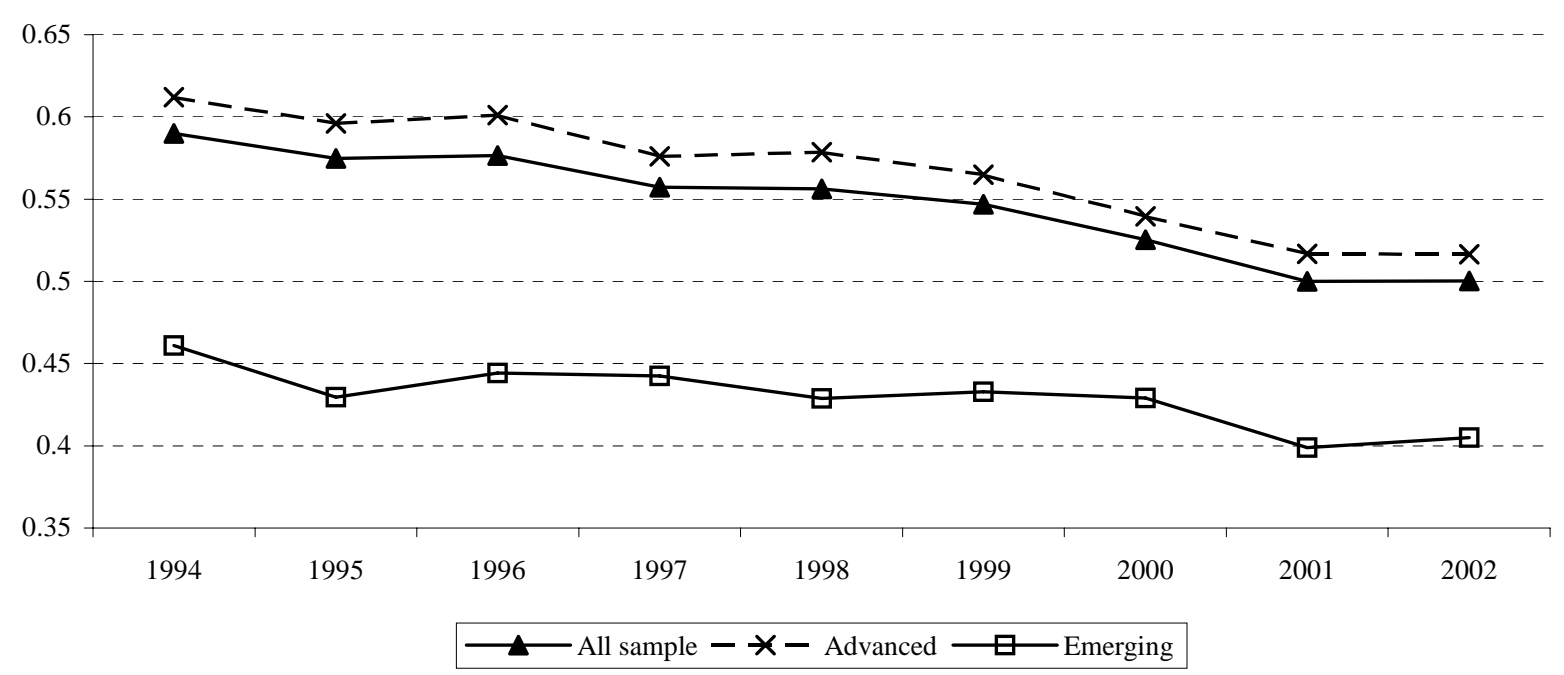

Figure 1B 


\section{Financial Openness}

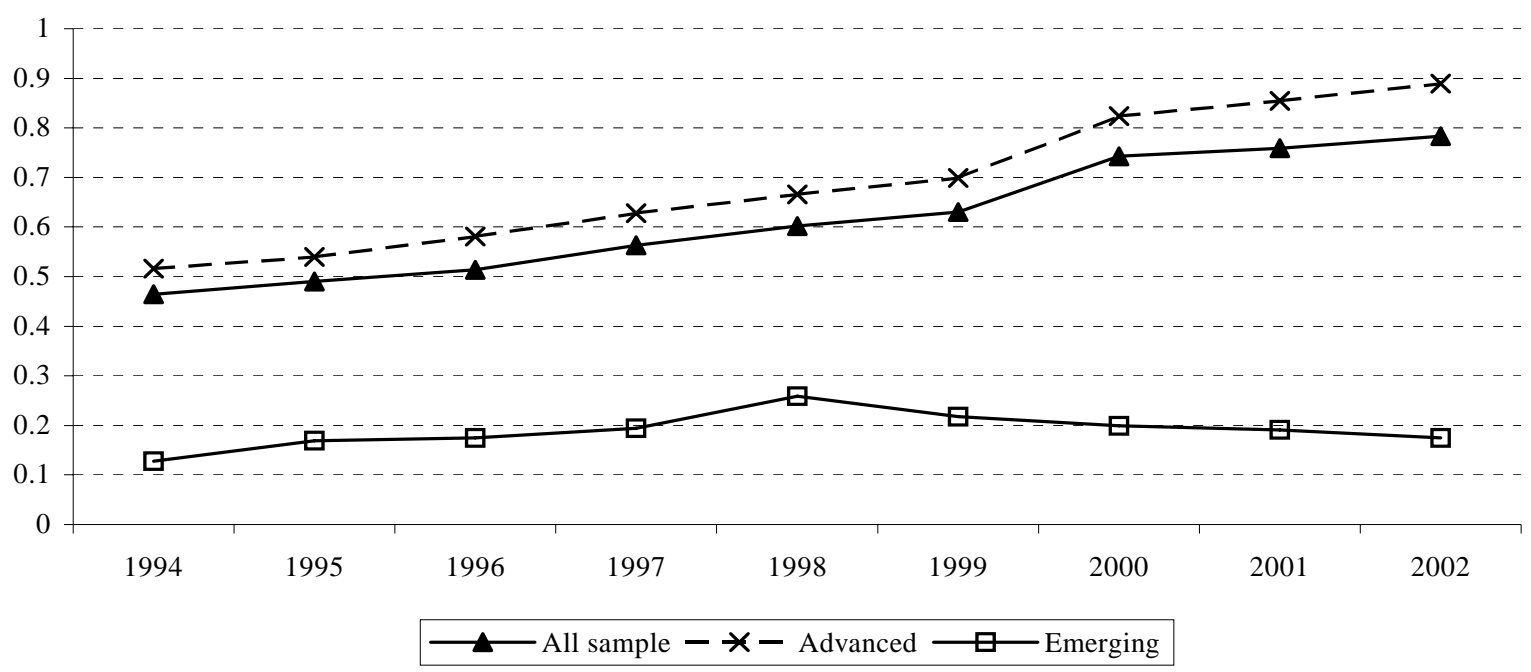

Figure 1C

\section{Financial liberalization index}

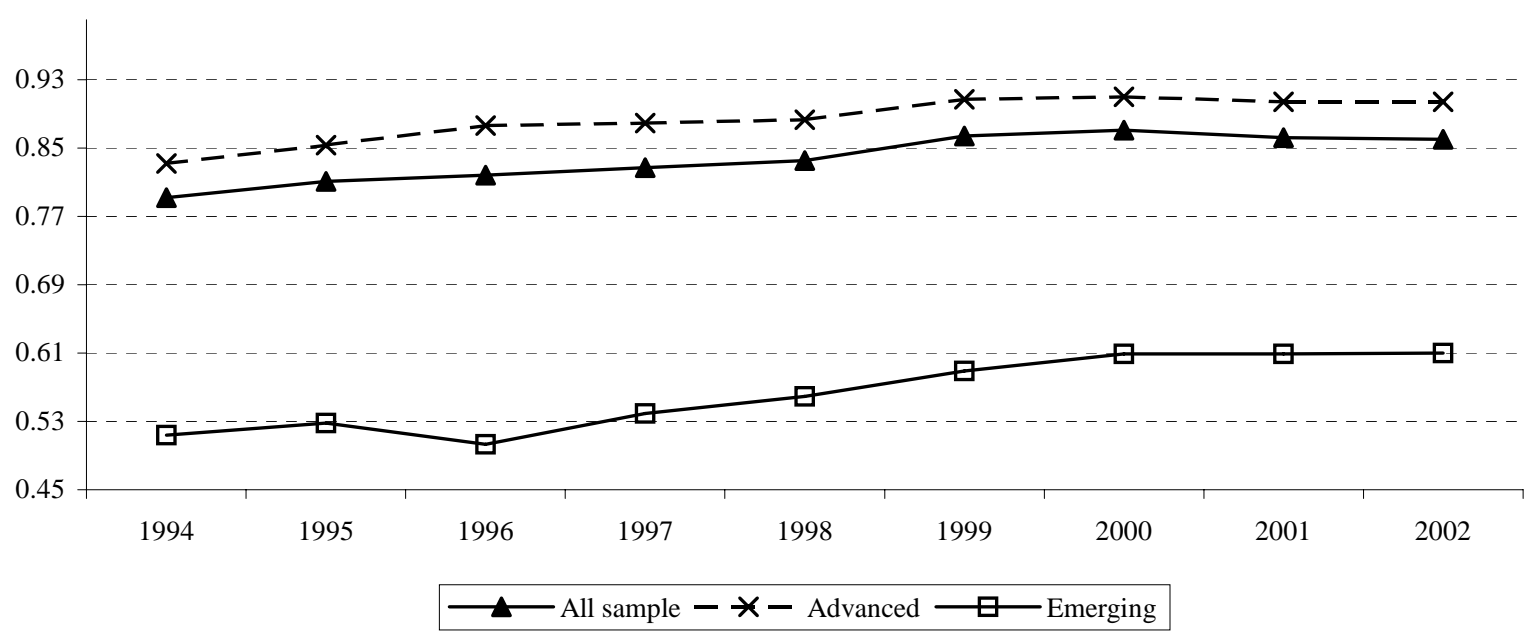

Figure 1D 


\section{Appendix}

Table A1

Country Level Observations

\begin{tabular}{|c|c|c|}
\hline & $\begin{array}{l}\text { Number of } \\
\text { firms }\end{array}$ & $\begin{array}{c}\text { Number of firm-year } \\
\text { observations }\end{array}$ \\
\hline ARGENTINA & 42 & 181 \\
\hline AUSTRALIA & 607 & 1796 \\
\hline AUSTRIA & 64 & 275 \\
\hline BELGIUM & 86 & 376 \\
\hline BRAZIL & 166 & 754 \\
\hline CANADA & 640 & 2587 \\
\hline CHILE & 99 & 520 \\
\hline CHINA & 166 & 547 \\
\hline COLOMBIA & 19 & 62 \\
\hline DENMARK & 110 & 679 \\
\hline FINLAND & 103 & 565 \\
\hline FRANCE & 640 & 2506 \\
\hline GERMANY & 628 & 3011 \\
\hline GREECE & 247 & 1085 \\
\hline HONG KONG & 502 & 2014 \\
\hline HUNGARY & 22 & 106 \\
\hline INDIA & 320 & 1755 \\
\hline INDONESIA & 203 & 915 \\
\hline ISRAEL & 71 & 248 \\
\hline ITALY & 174 & 862 \\
\hline JAPAN & 2804 & 13752 \\
\hline MALAYSIA & 530 & 2259 \\
\hline MEXICO & 88 & 443 \\
\hline NETHERLANDS & 145 & 667 \\
\hline NEW ZEALAND & 63 & 262 \\
\hline NORWAY & 109 & 541 \\
\hline PAKISTAN & 63 & 350 \\
\hline PERU & 45 & 148 \\
\hline PHILIPPINES & 87 & 393 \\
\hline POLAND & 50 & 119 \\
\hline PORTUGAL & 68 & 384 \\
\hline SINGAPORE & 343 & 1410 \\
\hline SPAIN & 94 & 595 \\
\hline SWEDEN & 207 & 945 \\
\hline THAILAND & 272 & 1525 \\
\hline TURKEY & 127 & 505 \\
\hline UNITED KINGDOM & 1074 & 6065 \\
\hline UNITED STATES & 5204 & 24940 \\
\hline TOTAL & 16282 & 76147 \\
\hline
\end{tabular}


Table A2

Pair-Wise Correlations

Panel A: Firm Level

\begin{tabular}{|c|c|c|c|c|c|c|c|}
\hline & $\begin{array}{c}\text { Debt } \\
\text { Maturity }\end{array}$ & $\begin{array}{c}\text { Growth } \\
\text { Opportunities } \\
\end{array}$ & Size & $\begin{array}{c}\text { Asset } \\
\text { Maturity }\end{array}$ & Tangibility & Profitability & Volatility \\
\hline Leverage & $\begin{array}{c}0.174 \\
(0.0001)\end{array}$ & $\begin{array}{c}-0.119 \\
(0.0001)\end{array}$ & $\begin{array}{c}0.074 \\
(0.0001)\end{array}$ & $\begin{array}{c}0.113 \\
(0.0001)\end{array}$ & $\begin{array}{c}0.251 \\
(0.0001)\end{array}$ & $\begin{array}{c}-0.066 \\
(0.0001)\end{array}$ & $\begin{array}{c}0.094 \\
(0.0001)\end{array}$ \\
\hline Debt Maturity & & $\begin{array}{c}0.019 \\
(0.0001)\end{array}$ & $\begin{array}{c}0.005 \\
(0.2074)\end{array}$ & $\begin{array}{c}0.068 \\
(0.0001)\end{array}$ & $\begin{array}{c}0.202 \\
(0.0001)\end{array}$ & $\begin{array}{c}0.117 \\
(0.0001)\end{array}$ & $\begin{array}{c}-0.111 \\
(0.0001)\end{array}$ \\
\hline Growth Opportunities & & & $\begin{array}{c}-0.024 \\
(0.0001)\end{array}$ & $\begin{array}{c}-0.052 \\
(0.0001)\end{array}$ & $\begin{array}{c}-0.134 \\
(0.0001)\end{array}$ & $\begin{array}{c}-0.160 \\
(0.0001)\end{array}$ & $\begin{array}{c}0.131 \\
(0.0001)\end{array}$ \\
\hline Size & & & & $\begin{array}{c}0.026 \\
(0.0001)\end{array}$ & $\begin{array}{c}0.038 \\
(0.0001)\end{array}$ & $\begin{array}{c}0.019 \\
(0.0001)\end{array}$ & $\begin{array}{c}-0.022 \\
(0.0001)\end{array}$ \\
\hline Asset Maturity & & & & & $\begin{array}{c}0.522 \\
(0.0001)\end{array}$ & $\begin{array}{c}0.021 \\
(0.0001)\end{array}$ & $\begin{array}{c}-0.060 \\
(0.0001)\end{array}$ \\
\hline Tangibility & & & & & & $\begin{array}{c}0.100 \\
(0.0001)\end{array}$ & $\begin{array}{c}-0.161 \\
(0.0001)\end{array}$ \\
\hline Profitability & & & & & & & $\begin{array}{c}-0.474 \\
(0.0001)\end{array}$ \\
\hline
\end{tabular}


Table A2 -continued

\section{Panel B: Country Level}

\begin{tabular}{|c|c|c|c|c|c|c|c|c|c|c|c|c|}
\hline & $\begin{array}{l}\text { Financial } \\
\text { Openness }\end{array}$ & $\begin{array}{c}\text { Share } \\
\text { Turnover }\end{array}$ & Inflation & $\begin{array}{c}\text { GDP per } \\
\text { Capita }\end{array}$ & $\begin{array}{c}\text { GDP } \\
\text { Growth }\end{array}$ & $\begin{array}{c}\text { Growth } \\
\text { Volatility }\end{array}$ & $\begin{array}{c}\text { Bank } \\
\text { Privatization }\end{array}$ & $\begin{array}{c}\text { Interest } \\
\text { Rates }\end{array}$ & $\begin{array}{c}\text { Bank } \\
\text { Supervision }\end{array}$ & $\begin{array}{c}\text { Securities } \\
\text { Markets }\end{array}$ & $\begin{array}{c}\text { Credit } \\
\text { Allocation }\end{array}$ & $\begin{array}{c}\text { Bank } \\
\text { Competition }\end{array}$ \\
\hline Financial Liberalization & $\begin{array}{c}0.375 \\
(0001)\end{array}$ & $\begin{array}{c}0.345 \\
(0001)\end{array}$ & $\begin{array}{l}-0.271 \\
(0001)\end{array}$ & $\begin{array}{c}0.878 \\
(0001)\end{array}$ & $\begin{array}{l}-0.046 \\
(0001)\end{array}$ & $\begin{array}{l}-0.213 \\
(0001)\end{array}$ & $\begin{array}{c}0.769 \\
(0001)\end{array}$ & $\begin{array}{c}0.640 \\
(0001)\end{array}$ & $\begin{array}{c}0.719 \\
(0001)\end{array}$ & $\begin{array}{c}0.835 \\
(0001)\end{array}$ & $\begin{array}{c}0.742 \\
(0001)\end{array}$ & $\begin{array}{c}0.521 \\
(0001)\end{array}$ \\
\hline Financial Openness & & $\begin{array}{l}-0.115 \\
(0001)\end{array}$ & $\begin{array}{l}-0.111 \\
(0001)\end{array}$ & $\begin{array}{c}0.229 \\
(0001)\end{array}$ & $\begin{array}{c}0.049 \\
(0001)\end{array}$ & $\begin{array}{l}-0.041 \\
(0001)\end{array}$ & $\begin{array}{c}0.307 \\
(0001)\end{array}$ & $\begin{array}{c}0.192 \\
(0001)\end{array}$ & $\begin{array}{c}0.200 \\
(0001)\end{array}$ & $\begin{array}{c}0.279 \\
(0001)\end{array}$ & $\begin{array}{c}0.330 \\
(0001)\end{array}$ & $\begin{array}{c}0.316 \\
(0001)\end{array}$ \\
\hline Share Turnover & & & $\begin{array}{c}0.068 \\
(0001)\end{array}$ & $\begin{array}{c}0.293 \\
(0001)\end{array}$ & $\begin{array}{l}-0.020 \\
(0001)\end{array}$ & $\begin{array}{l}-0.276 \\
(0001)\end{array}$ & $\begin{array}{c}0.200 \\
(0001)\end{array}$ & $\begin{array}{c}0.079 \\
(0001)\end{array}$ & $\begin{array}{c}0.513 \\
(0001)\end{array}$ & $\begin{array}{c}0.169 \\
(0001)\end{array}$ & $\begin{array}{c}0.382 \\
(0001)\end{array}$ & $\begin{array}{c}0.056 \\
(0001)\end{array}$ \\
\hline Inflation & & & & $\begin{array}{l}-0.403 \\
(0001)\end{array}$ & $\begin{array}{l}-0.081 \\
(0001)\end{array}$ & $\begin{array}{c}0.208 \\
(0001)\end{array}$ & $\begin{array}{l}-0.264 \\
(0001)\end{array}$ & $\begin{array}{l}-0.078 \\
(0001)\end{array}$ & $\begin{array}{l}-0.141 \\
(0001)\end{array}$ & $\begin{array}{l}-0.386 \\
(0001)\end{array}$ & $\begin{array}{l}-0.125 \\
(0001)\end{array}$ & $\begin{array}{l}-0.100 \\
(0001)\end{array}$ \\
\hline GDP per Capita & & & & & $\begin{array}{l}-0.091 \\
(0001)\end{array}$ & $\begin{array}{l}-0.321 \\
(0001)\end{array}$ & $\begin{array}{c}0.657 \\
(0001)\end{array}$ & $\begin{array}{c}0.580 \\
(0001)\end{array}$ & $\begin{array}{c}0.597 \\
(0001)\end{array}$ & $\begin{array}{c}0.899 \\
(0001)\end{array}$ & $\begin{array}{c}0.518 \\
(0001)\end{array}$ & $\begin{array}{c}0.461 \\
(0001)\end{array}$ \\
\hline GDP Growth & & & & & & $\begin{array}{l}-0.185 \\
(0001)\end{array}$ & $\begin{array}{c}0.023 \\
(0001)\end{array}$ & $\begin{array}{l}-0.163 \\
(0001)\end{array}$ & $\begin{array}{c}0.060 \\
(0001)\end{array}$ & $\begin{array}{l}-0.122 \\
(0001)\end{array}$ & $\begin{array}{c}0.097 \\
(0001)\end{array}$ & $\begin{array}{l}-0.197 \\
(0001)\end{array}$ \\
\hline Growth Volatility & & & & & & & $\begin{array}{l}-0.087 \\
(0001)\end{array}$ & $\begin{array}{l}-0.114 \\
(0001)\end{array}$ & $\begin{array}{l}-0.257 \\
(0001)\end{array}$ & $\begin{array}{l}-0.315 \\
(0001)\end{array}$ & $\begin{array}{l}-0.143 \\
(0001)\end{array}$ & $\begin{array}{c}0.030 \\
(0001)\end{array}$ \\
\hline Bank Privatization & & & & & & & & $\begin{array}{c}0.355 \\
(0001)\end{array}$ & $\begin{array}{c}0.538 \\
(0001)\end{array}$ & $\begin{array}{c}0.519 \\
(0001)\end{array}$ & $\begin{array}{c}0.470 \\
(0001)\end{array}$ & $\begin{array}{c}0.156 \\
(0001)\end{array}$ \\
\hline Interest Rates & & & & & & & & & $\begin{array}{c}0.173 \\
(0001)\end{array}$ & $\begin{array}{c}0.657 \\
(0001)\end{array}$ & $\begin{array}{c}0.355 \\
(0001)\end{array}$ & $\begin{array}{c}0.502 \\
(0001)\end{array}$ \\
\hline Bank Supervision & & & & & & & & & & $\begin{array}{c}0.502 \\
(0001)\end{array}$ & $\begin{array}{c}0.585 \\
(0001)\end{array}$ & $\begin{array}{c}0.069 \\
(0001)\end{array}$ \\
\hline Securities Markets & & & & & & & & & & & $\begin{array}{c}0.523 \\
(0001)\end{array}$ & $\begin{array}{c}0.466 \\
(0001)\end{array}$ \\
\hline Credit Allocation & & & & & & & & & & & & $\begin{array}{c}0.215 \\
(3039)\end{array}$ \\
\hline
\end{tabular}


Table A2 -continued

Panel C: Firm with Country Level

\begin{tabular}{|c|c|c|c|c|c|c|c|c|c|c|c|c|c|}
\hline & $\begin{array}{c}\text { Financial } \\
\text { Liberalization } \\
\end{array}$ & $\begin{array}{l}\text { Financial } \\
\text { Openness } \\
\end{array}$ & $\begin{array}{c}\text { Share } \\
\text { Turnover }\end{array}$ & Inflation & $\begin{array}{l}\text { GDP per } \\
\text { Capita }\end{array}$ & $\begin{array}{c}\text { GDP } \\
\text { Growth }\end{array}$ & $\begin{array}{c}\text { Growth } \\
\text { Volatility }\end{array}$ & $\begin{array}{c}\text { Bank } \\
\text { Privatization }\end{array}$ & $\begin{array}{c}\text { Interest } \\
\text { Rates }\end{array}$ & $\begin{array}{c}\text { Bank } \\
\text { Supervision } \\
\end{array}$ & $\begin{array}{c}\text { Securities } \\
\text { Markets }\end{array}$ & $\begin{array}{c}\text { Credit } \\
\text { Allocation } \\
\end{array}$ & $\begin{array}{c}\text { Bank } \\
\text { Competition } \\
\end{array}$ \\
\hline Leverage & $\begin{array}{c}-0.102 \\
(0.0001)\end{array}$ & $\begin{array}{c}-0.121 \\
(0.0001)\end{array}$ & $\begin{array}{c}0.005 \\
(0.1509)\end{array}$ & $\begin{array}{c}0.029 \\
(0.0001)\end{array}$ & $\begin{array}{c}-0.086 \\
(0.0001)\end{array}$ & $\begin{array}{c}-0.045 \\
(0.0001)\end{array}$ & $\begin{array}{c}0.033 \\
(0.0001)\end{array}$ & $\begin{array}{c}-0.086 \\
(0.0001)\end{array}$ & $\begin{array}{c}-0.034 \\
(0.0001)\end{array}$ & $\begin{array}{c}-0.092 \\
(0.0001)\end{array}$ & $\begin{array}{c}-0.088 \\
(0.0001)\end{array}$ & $\begin{array}{c}-0.092 \\
(0.0001)\end{array}$ & $\begin{array}{c}-0.022 \\
(0.0001)\end{array}$ \\
\hline Debt Maturity & $\begin{array}{c}0.191 \\
(0.0001)\end{array}$ & $\begin{array}{c}-0.030 \\
(0.0001)\end{array}$ & $\begin{array}{c}0.162 \\
(0.0001)\end{array}$ & $\begin{array}{c}-0.015 \\
(0.0001)\end{array}$ & $\begin{array}{c}0.154 \\
(0.0001)\end{array}$ & $\begin{array}{c}0.063 \\
(0.0001)\end{array}$ & $\begin{array}{c}-0.098 \\
(0.0001)\end{array}$ & $\begin{array}{c}0.191 \\
(0.0001)\end{array}$ & $\begin{array}{c}0.079 \\
(0.0001)\end{array}$ & $\begin{array}{c}0.232 \\
(0.0001)\end{array}$ & $\begin{array}{c}0.131 \\
(0.0001)\end{array}$ & $\begin{array}{c}0.198 \\
(0.0001)\end{array}$ & $\begin{array}{c}-0.070 \\
(0.0001)\end{array}$ \\
\hline Growth Opportunities & $\begin{array}{c}0.117 \\
(0.0001)\end{array}$ & $\begin{array}{c}0.022 \\
(0.0001)\end{array}$ & $\begin{array}{c}0.113 \\
(0.0001)\end{array}$ & $\begin{array}{c}0.025 \\
(0.0001)\end{array}$ & $\begin{array}{c}0.085 \\
(0.0001)\end{array}$ & $\begin{array}{c}0.105 \\
(0.0001)\end{array}$ & $\begin{array}{c}-0.083 \\
(0.0001)\end{array}$ & $\begin{array}{c}0.115 \\
(0.0001)\end{array}$ & $\begin{array}{c}0.011 \\
(0.0041)\end{array}$ & $\begin{array}{c}0.163 \\
(0.0001)\end{array}$ & $\begin{array}{c}0.056 \\
(0.0001)\end{array}$ & $\begin{array}{c}0.155 \\
(0.0001)\end{array}$ & $\begin{array}{c}-0.059 \\
(0.0001)\end{array}$ \\
\hline Size & $\begin{array}{c}-0.101 \\
(0.0001)\end{array}$ & $\begin{array}{c}-0.049 \\
(0.0001)\end{array}$ & $\begin{array}{c}-0.075 \\
(0.0001)\end{array}$ & $\begin{array}{c}0.068 \\
(0.0001)\end{array}$ & $\begin{array}{c}-0.112 \\
(0.0001)\end{array}$ & $\begin{array}{c}-0.044 \\
(0.0001)\end{array}$ & $\begin{array}{c}0.079 \\
(0.0001)\end{array}$ & $\begin{array}{c}-0.120 \\
(0.0001)\end{array}$ & $\begin{array}{c}0.021 \\
(0.0001)\end{array}$ & $\begin{array}{c}-0.151 \\
(0.0001)\end{array}$ & $\begin{array}{c}-0.073 \\
(0.0001)\end{array}$ & $\begin{array}{c}-0.092 \\
(0.0001)\end{array}$ & $\begin{array}{c}0.034 \\
(0.0001)\end{array}$ \\
\hline Asset Maturity & $\begin{array}{l}-0.153 \\
(0.0001)\end{array}$ & $\begin{array}{c}0.007 \\
(0.0501)\end{array}$ & $\begin{array}{l}-0.151 \\
(0.0001)\end{array}$ & $\begin{array}{c}0.031 \\
(0.0001)\end{array}$ & $\begin{array}{l}-0.175 \\
(0.0001)\end{array}$ & $\begin{array}{c}0.006 \\
(0.1216)\end{array}$ & $\begin{array}{c}0.128 \\
(0.0001)\end{array}$ & $\begin{array}{l}-0.055 \\
(0.0001)\end{array}$ & $\begin{array}{l}-0.115 \\
(0.0001)\end{array}$ & $\begin{array}{l}-0.154 \\
(0.0001)\end{array}$ & $\begin{array}{c}-0.163 \\
(0.0001)\end{array}$ & $\begin{array}{c}-0.122 \\
(0.0001)\end{array}$ & $\begin{array}{c}-0.053 \\
(0.0001)\end{array}$ \\
\hline Tangibility & $\begin{array}{l}-0.159 \\
(0.0001)\end{array}$ & $\begin{array}{c}-0.036 \\
(0.0001)\end{array}$ & $\begin{array}{c}-0.138 \\
(0.0001)\end{array}$ & $\begin{array}{c}0.053 \\
(0.0001)\end{array}$ & $\begin{array}{c}-0.193 \\
(0.0001)\end{array}$ & $\begin{array}{c}0.010 \\
(0.0091)\end{array}$ & $\begin{array}{c}0.130 \\
(0.0001)\end{array}$ & $\begin{array}{c}-0.082 \\
(0.0001)\end{array}$ & $\begin{array}{c}-0.086 \\
(0.0001)\end{array}$ & $\begin{array}{c}-0.139 \\
(0.0001)\end{array}$ & $\begin{array}{c}-0.171 \\
(0.0001)\end{array}$ & $\begin{array}{c}-0.114 \\
(0.0001)\end{array}$ & $\begin{array}{c}-0.070 \\
(0.0001)\end{array}$ \\
\hline Profitability & $\begin{array}{c}-0.154 \\
(0.0001)\end{array}$ & $\begin{array}{c}-0.023 \\
(0.0001)\end{array}$ & $\begin{array}{c}-0.178 \\
(0.0001)\end{array}$ & $\begin{array}{c}0.066 \\
(0.0001)\end{array}$ & $\begin{array}{c}-0.153 \\
(0.0001)\end{array}$ & $\begin{array}{c}0.045 \\
(0.0001)\end{array}$ & $\begin{array}{c}0.027 \\
(0.0001)\end{array}$ & $\begin{array}{c}-0.133 \\
(0.0001)\end{array}$ & $\begin{array}{c}-0.055 \\
(0.0001)\end{array}$ & $\begin{array}{c}-0.137 \\
(0.0001)\end{array}$ & $\begin{array}{c}-0.102 \\
(0.0001)\end{array}$ & $\begin{array}{c}-0.105 \\
(0.0001)\end{array}$ & $\begin{array}{c}-0.091 \\
(0.0001)\end{array}$ \\
\hline Volatility & $\begin{array}{c}0.127 \\
(0.0001)\end{array}$ & $\begin{array}{c}-0.064 \\
(0.0001)\end{array}$ & $\begin{array}{c}0.340 \\
(0.0001)\end{array}$ & $\begin{array}{c}0.078 \\
(0.0001)\end{array}$ & $\begin{array}{c}0.090 \\
(0.0001)\end{array}$ & $\begin{array}{c}-0.085 \\
(0.0001)\end{array}$ & $\begin{array}{c}-0.005 \\
(0.1674)\end{array}$ & $\begin{array}{c}0.110 \\
(0.0001)\end{array}$ & $\begin{array}{c}0.015 \\
(0.0001)\end{array}$ & $\begin{array}{c}0.167 \\
(0.0001)\end{array}$ & $\begin{array}{c}0.016 \\
(0.0001)\end{array}$ & $\begin{array}{c}0.129 \\
(0.0001)\end{array}$ & $\begin{array}{c}0.063 \\
(0.0001)\end{array}$ \\
\hline
\end{tabular}




\section{References}

Abiad, Abdul, Daniel Leigh, and Ashoka Mody, 2007, "International Finance and Income Convergence: Europe is Different,” forthcoming in IMF Working Paper series.

Abiad, Abdul, Enrica Detragiche, and Thierry Tressel, 2007, “A New Database of Financial Reforms”(unpublished; Washington: International Monetary Fund).

Alfaro, Laura, and Eliza Hammel, 2007, “Capital Flows and Capital Goods,” Journal of International Economics, Vol. 72, No. 1, pp. 128-50.

Barclay, Michael J., and Clifford W. Smith, Jr., 1995, “The Maturity Structure of Corporate Debt,” Journal of Finance, Vol. 50, pp. 609-31.

Barclay, Michael J., Leslie M. Marx, and Clifford Smith Jr., 2003, “The Joint Determination of Leverage and Maturity,” Journal of Corporate Finance, Vol. 9, pp. 149-60.

Beck, Thorsten, and Ed Al-Hussainy, 2006, “Financial Structure Dataset,” (World Bank) February 2.

Bekaert, Geert, and Campbell Harvey, 2000, “Foreign Speculators and Emerging Equity Markets,” Journal of Finance, Vol. 55, No. 2, pp. 565-613.

Bekaert, Geert, Campbell Harvey, and Christian Lundblad, 2007, “Global Growth Opportunities and Market Integration,” Journal of Finance, Vol. 62(3), pp. 1081-137.

_ 2005, “Does Financial Liberalization Spur Growth?” Journal of Financial Economics, Vol. 77, pp. 3-55.

Berglöf, Erik, and Ernst-Ludwig Von Thadden, 1994, “Short-Term Versus Long-Term Interests,” Quarterly Journal of Economics, Vol. 109, pp. 1055-84.

Bertrand, Marianne, Antoinette Schoar, and David Thesmar, 2004, "Banking Deregulation and Industry Structure: Evidence from the 1985 French Banking Act”, CEPR Discussion Paper 4488.

Booth, Lawrence, and others, 2001, “Capital Structures in Developing Countries,” Journal of Finance, Vol. 56, pp. 87-130.

Brick, Ivan E., and Abraham S. Ravid, 1985, “The Relevance of Debt Maturity Structure,” Journal of Finance, Vol. 40, pp. 1423-37.

Cetorelli, Nicola, and Philip E. Strahan, 2006, "Finance as a Barrier to Entry: Bank Competition and Industry Structure in Local U.S. Markets,” Journal of Finance, Vol. 61, No. 1, pp. 437-61. 
Demirgüç-Kunt, Asli, and Enrica Detragiache, 1999, "Financial Liberalization and Financial Fragility,” in Annual World Bank Conference on Development Economics 1998, ed. by Pleskovic and Stiglitz (Washington: The World Bank).

Demirgüç-Kunt, Asli, and Vojislav Maksimovic, 1999, "Institutions, Financial Markets, and Firm Debt Maturity,” Journal of Finance, Vol.10, pp. 341-69.

Diamond, Douglas, W., 1991, “Debt Maturity Structure and Liquidity Risk,” Quarterly Journal of Economics, Vol. 106, No. 3, pp. 709-37.

Diamond, Douglas, W., 2004, “Committing to Commit: Short-Term Debt When Enforcement Is Costly,” Journal of Finance, Vol. 59, No. 4, pp.1447-79.

Djankov, Simeon, Caralee McLiesh, and Andrei Shleifer, 2007, “Private Credit in 129 Countries,” forthcoming in Journal of Financial Economics.

Fan, Joseph P. H., Sheridan Titman, and Garry Twite, 2006, “An International Comparison of Capital Structure and Debt Maturity Choices,” University of Texas, Austin, working paper.

Gertler, Mark, and Simon Gilchrist, 1993, “The Cyclical Behavior of Short-Term Business Lending,” European Economic Review, Vol. 37, pp. 623-31.

Giannetti, Mariassunta, 2003, “Do Better Institutions Mitigate Agency Problems,” Journal of Financial and Quantitative Analysis, Vol. 38, pp. 185-212.

Guiso, Luigi, Paola Sapienza, and Luigi Zingales, 2006, “The Cost of Banking Regulation,” NBER Working Paper No. 12501.

Harkbarth, Dick, Jianjun Miao and Erwan Morellec, 2006, "Capital Structure, Credit Risk, and Macroeconomic Conditions,” Journal of Financial Economics, Vol. 82, No. 3, pp. 519-50.

Harris, Milton and Artur Raviv, 1991, “The Theory of Capital Structure,” Journal of Finance, Vol. 46, pp. 297-355.

Henry, Peter B., 2000a, "Stock Market Liberalization, Economic Reform, and Emerging Market Equity Prices,” Journal of Finance, Vol. 55, pp. 529-64.

, 2000b, “Do Stock Market Liberalizations Cause an Investment Boom?” Journal of Financial Economics, Vol. 58, 301-34.

_ , 2006, “Capital Account Liberalization: Theory, Evidence, and Speculation,” NBER Working Paper No. 12698.

International Monetary Fund, 2006, World Economic Outlook, September 2005, World Economic Surveys (Washington).. 
Jayaratne, Jith, and Philip E. Strahan, 1996, The Finance-Growth Nexus: Evidence from Bank-Branch Deregulation, Quarterly Journal of Economics, Vol. 108, pp. 717-38.

Kaminsky, Graciela, and Sergio L. Schmukler, 2003, "Short-Term Pain, Long-Run Gain: The Effects of Financial Liberalization,” NBER Working Paper No. 9787.

Korajczyk, Robert A., and Amnon Levy, 2003, “Capital Structure Choice: Macroeconomic Conditions and Financial Constraints,” Journal of Financial Economics, Vol. 68, pp. 75-109.

Kose, Ayhan, and others, 2006, Financial Globalization: A Reappraisal, NBER Working Paper No. 12484.

La Porta, Rafael, and others, 1998, “Law and Finance,” Journal of Political Economy, Vol. 106, pp. 1113-55.

Myers, Stewart, 1977, “Determinants of Corporate Borrowing,” Journal of Financial Economics, Vol. 5, pp. 147-75.

Myers, Stewart, 2004, “Financing of Corporations," in Handbook of the Economics of Finance, ed. by G.M. Constantinides, M. Harris and R. Stulz (North Holand: Elsevier).

Qian, Jun, and Philip E. Strahan, 2007, "How Laws and Institutions Shape Financial Contracts: The Case of Bank Loans,” forthcoming in Journal of Finance.

Rajan, Raghuram, and Luigi Zingales, 1995, "What Do We Know About Capital Structure? Some Evidence from International Data,” Journal of Finance, Vol. 50, No. 5, pp. 1421-60.

Schmukler, Sergio L., and Esteban Vesperoni, 2006, "Financial Globalization and Debt Maturity in Emerging Economies,” Journal of Development Economics, Vol. 79, pp. 183-207.

Stiroh, Kevin J., and Philip E. Strahan, 2003, "Competitive Dynamics of Deregulation: Evidence from U.S. Banking,” Journal of Money, Credit and Banking, Vol. 35, No. 5, pp. 801-28.

Stohs, Mark H., and David C. Mauer, 1996, The Determinants of Corporate Debt Maturity Structure, Journal of Business, 69, 279-312.

Stulz, Rene, 2005, “The Limits to Financial Globalization,” Journal of Finance, Vol. 60, pp. 1595-638.

Townsend, Robert, and Kenichi Ueda, 2006, “Welfare Gains from Financial Liberalization,” (unpublished; Washington: International Monetary Fund). 